\title{
Influence of the Subtropical Andes on Baroclinic Disturbances: A Cold Front Case Study
}

\author{
Marcelo E. Seluchi \\ Centro de Previsão de Tempo e Estudos Climáticos-INPE, São Paulo, Brazil \\ René D. Garreaud \\ Department of Geophysics, Universidad de Chile, Santiago, Chile
}

FEDERICO A. NORTE

Programa Regional de Meteorología, Instituto Argentino de Nivología y Glaciología (IANIGLA)-CONICET, Mendoza, Argentina

\section{A. Celeste Saulo}

Centro de Investigaciones del Mar y la Atmósfera-CONICET, and Departamento de Ciencias de la Atmósfera y los Océanos, Universidad de Buenos Aires, Buenos Aires, Argentina

(Manuscript received 23 September 2005, in final form 24 January 2006)

\begin{abstract}
The Andes Cordillera produces a significant disruption to the structure and evolution of the weather systems that cross South America. In particular, cold fronts tend to be "channeled" to the north immediately to the east of the Andes, fostering the advance of cold air incursions (cold surges) well into subtropical, and sometimes tropical, latitudes. In contrast, active cold fronts hardly reach subtropical latitudes along the western side of the Andes (Pacific sea border). Instead, as a cold front moves equatorward along the east side of the Andes, a marked low-level warming tends to appear along the west side of the subtropical Andes, leading to the formation of a mesoscale coastal low (or trough) in this region. To further understand the processes that lead to a contrasting evolution of the cold front at each side of the Andes, a typical frontal passage is studied in this work, using synoptic observations and a regional model [Eta-Centro de Previsão de Tempo e Estudos Climáticos (CPTEC)] simulation.

The passage of the postfrontal anticyclone over southern South America produces a poleward-pointing pressure gradient and, hence, geostrophic easterly flow at low levels. The tall and steep mountains block the flow, leading to a very small zonal wind component close to the slopes. Convergence (divergence) of the zonal flow to the east (west) of the subtropical Andes is largely compensated for by upward (downward) motion, and the associated cooling (warming) over this region. The weak zonal wind component near the Andes also breaks down the geostrophic balance over this region, giving rise to an acceleration of the southerly winds (i.e., along-barrier flow) and the consequent increase in cold advection. Therefore, to the east of the subtropical Andes both horizontal and vertical advection cool the lower troposphere, fostering the equatorward propagation of the cold front. To the west of the Andes, horizontal advection is largely offset by the strong warming associated with the enhanced subsidence over that region hindering the advance of the cold front into subtropical latitudes.
\end{abstract}

\section{Introduction}

The Andes Cordillera is the largest and tallest mountain range in the Southern Hemisphere, running con-

Corresponding author address: Dr. René Garreaud, P.O. Box 025285, Miami, FL 33102-5285.

E-mail: rgarreau@dgf.uchile.cl tinuously very close to the Pacific sea border of South America. It impacts the atmospheric circulation of the continent in a broad range of scales, from the generation of mesoscale mountain waves (e.g., Seluchi et al. 2003a) up to the positioning of planetary standing waves (e.g., Satyamurty et al. 1980). Between the southern tip of the continent and $38^{\circ} \mathrm{S}$, the Andes elevation ranges between 1500 and $2500 \mathrm{~m}$ (Fig. 1) and then it 

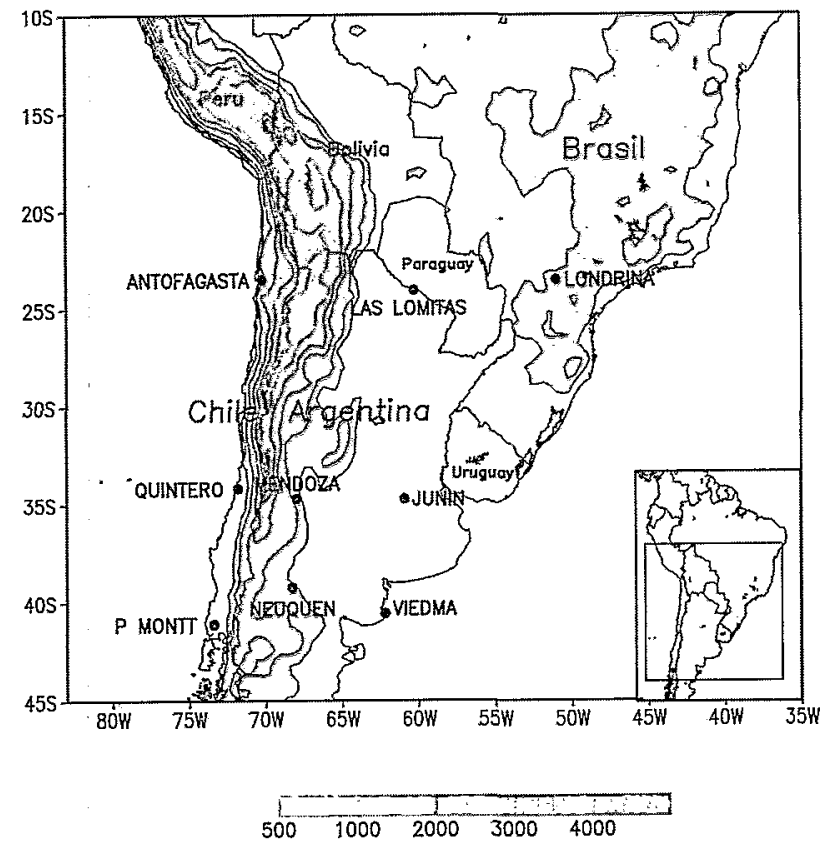

FIG. 1. Topographic map of southern South America (elevations higher than $500 \mathrm{~m}$ are shaded) and locations of the meteorological stations.

rises sharply to about $5000 \mathrm{~m}$ ASL at subtropical latitudes $\left(25^{\circ}-35^{\circ} \mathrm{S}\right)$. Thus, the subtropical Andes strongly block the zonal flow and separate two distinctive climatic regimes: a relatively cold and dry regime to the west, and a warmer and moister regime to the east (Seluchi and Marengo 2000).

At the synoptic scale, the Andes produce a marked disruption in the structure and evolution of the weather systems that cross the continent. Midlatitude cyclones and anticyclones are "channeled" to the north immediately to the east of the Andes, fostering their extent into subtropical and tropical latitudes at the same time that their midlatitude cores move eastward (Gan and Rao 1994; Seluchi et al. 1998). Thus, cold fronts reach low latitudes several times per month. During wintertime, cold air incursions (sometime referred to as cold surges) might produce frost events as far north as southern Brazil and central Bolivia (e.g., Fortune and Kousky 1983; Hamilton and Tarifa 1978; Marengo et al. 1997; Garreaud 2000; Vera and Vigliarolo 2000) with major social and economic impacts. In contrast, frontal systems moving along the western side of the Andes (eastern Pacific) hardly reach subtropical latitudes with a noticeable effect (Ogaz and Fuenzalida 1981), partially explaining the extreme aridity of northern Chile and southern Peru. Furthermore, as documented by Garreaud et al. (2002), when a warm ridge aloft approaches the continent, surface pressure to the west of the Andes tends to drop, leading to the formation of a coastal trough or low over ce:atral Chile. The physical mechanism behind this association was addressed in a modeling study by Garreaud and Rutllant (2003), and is further explored in this work. Such coastal depressions are accompanied by warm ani dry conditions near the coast and farther inland, and strong low-level easterly flow down the Andean foothills [the so-called raco winds; Rutllant and Garreaud (2004)].

Synoptic experience and observational evidence (Gan and Rao 1994; Seluchi et al. 1998; Garreand 2000) indicate that cold air incursions to the east of the subtropical Andes and coastal depressions to the west tend to develop simultaneously, after the passage of a surface cold front over southern South America and in concert with the approach of a ridge aloft. Nevertheless, the dominant process behind the disruption of the synoptic-scale circulation is different across the mountain range, so as to produce opposite pressure tendencies and such a marked difference in the frontal displacement at each side of the subtropical Andes.

Orographic influence on frontal systems is a common feature at other locations around the world. Colle and Mass (1995), among others, analyzed northerly cold surges that move preferentially along the eastern side of the Rockies. These surges sometimes can reach as far south as the Caribbean and Central America as reviewed by Schultz et al. (1997). On the other side, coastal troughs along the North American west coast (Mass and Albright 1987; Nuss et al. 2000) are sometimes observed to be associated with offshore flow. Coastal lows are also often observed around the coast of South Africa (Gill 1982; Reason and Jury 1990). Severe cold fronts that move along the eastern coast of Australia during spring and summer are known as "southerly busters." In those cases the leading edge of the front is usually deformed due to the orographical influence, acquiring an "S" shape (McInnes and McBride 1993).

To further understand the processes that lead to the contrasting evolutions of cold fronts on each side of the Andes, a typical frontal passage is studied in this work. The cold front was followed by a well-defined cold air incursion (to the east) and coastal low (to the west). To augment the observational dataset used (described in section 2), the case was simulated numerically using the Eta-Centro de Previsão de Tempo e Estudos Climáti$\cos$ (CPTEC) model (detailed in section 3). The model results were validated and used to diagnose the episode in section 4. Our conclusions are presented in section 5.

\section{Episode overview}

The selected case illustrates a typical frontal passage over southern South America, which took place from 
a. 1200 UTC 13 April
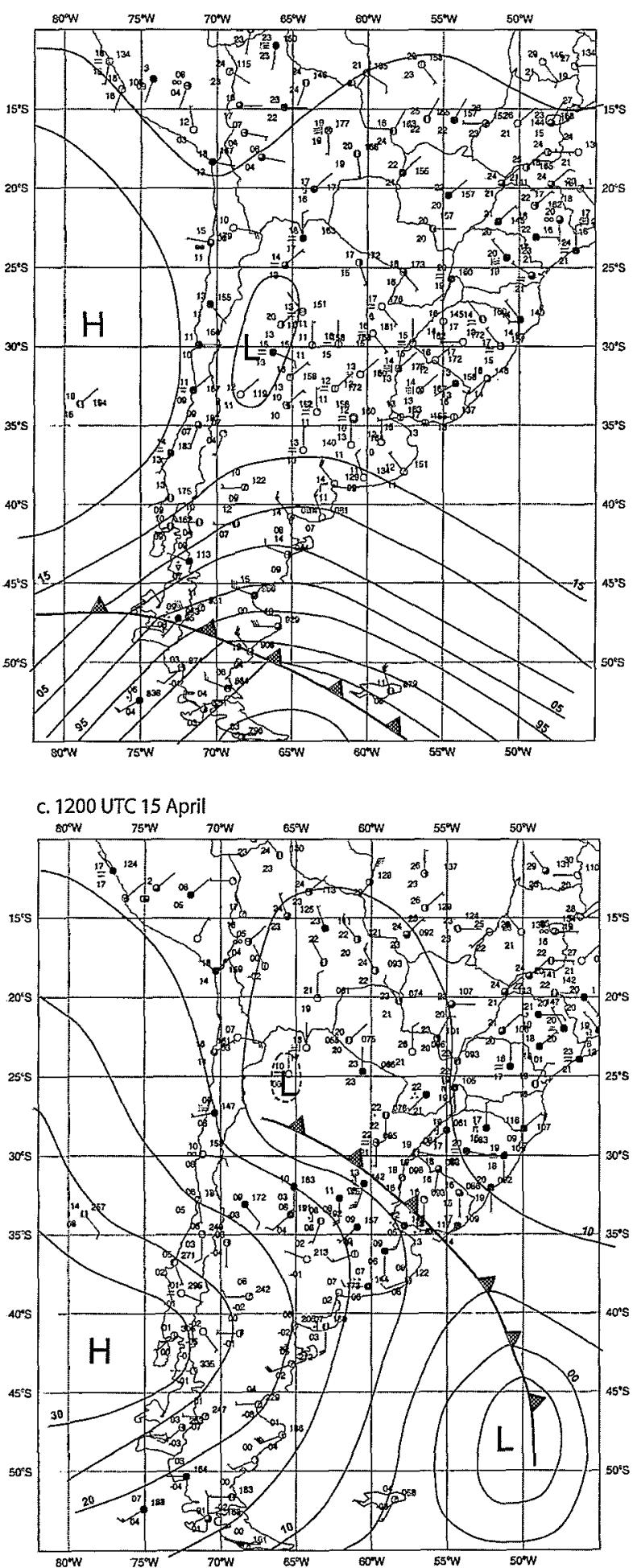

b. 1200 UTC 14 April

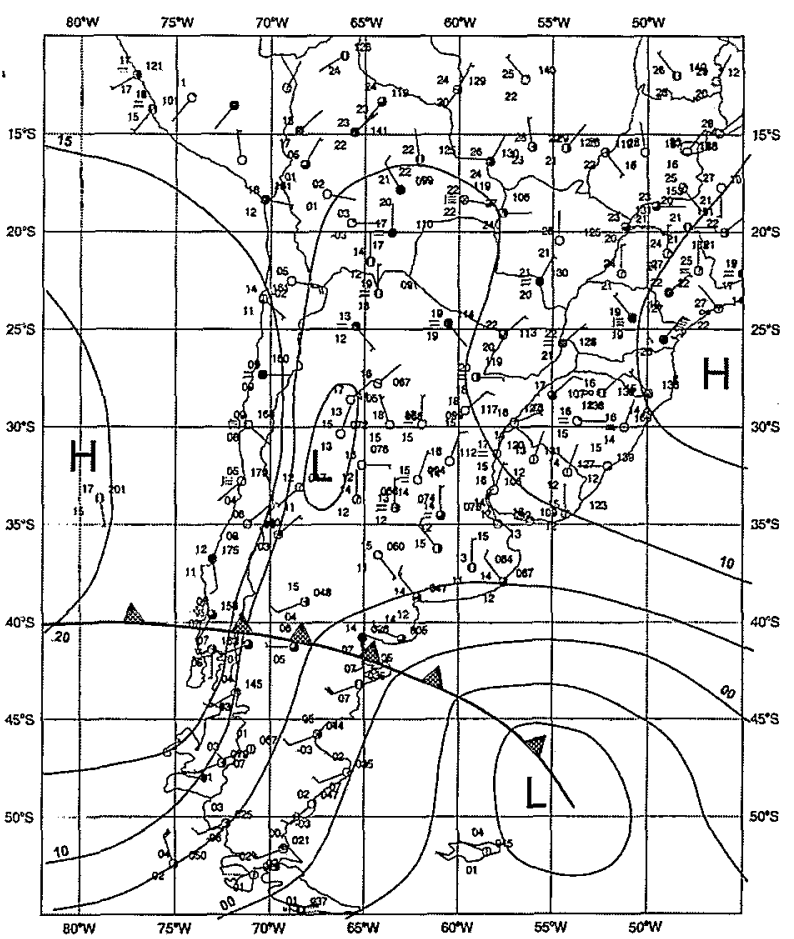

d. 1200 UTC 16 April

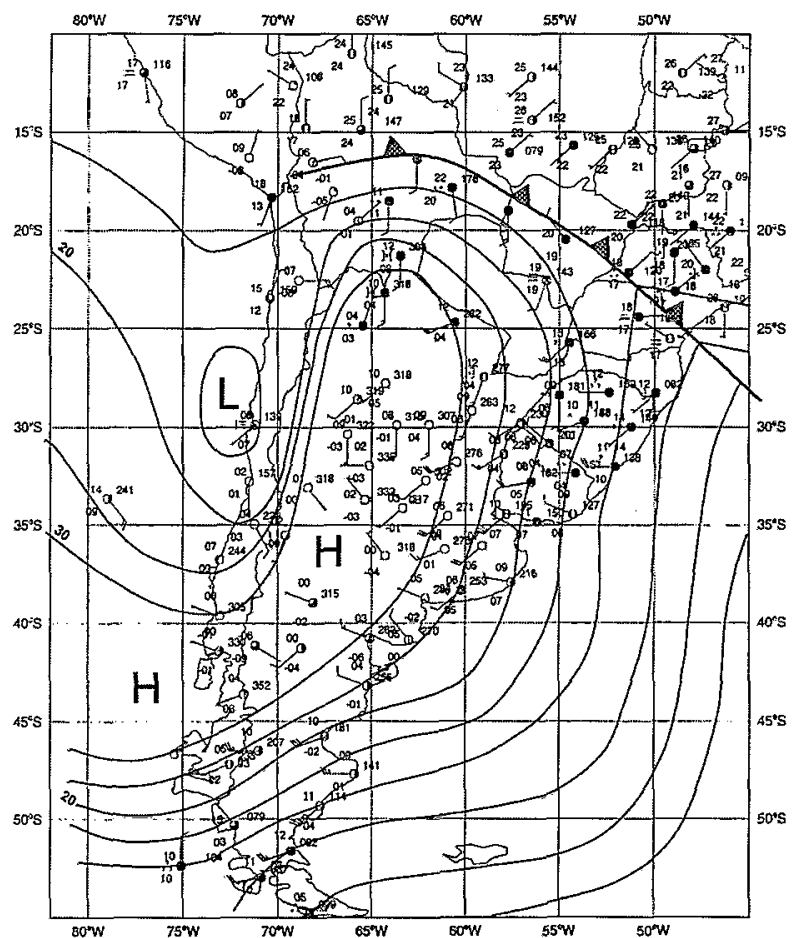

FIg. 2. Surface analyses at (a) 1200 UTC 13 Apr, (b) 1200 UTC 14 Apr, (c) 1200 UTC 15 Apr, and (d) 1200 UTC 16 Apr 1999 . Isobars (solid lines) are drawn at 5 -hPa intervals (only the two last numbers are plotted) and wind barbs are in knots $\left(1 \mathrm{kt} \approx 0.5144 \mathrm{~m} \mathrm{~s}{ }^{-1}\right)$.

13 to 18 April 1999. In this section we present an overview of the episode using surface and upper-air maps based on conventional synoptic reports.

On 13 April (Fig. 2a), a zonally oriented cold front reached the southern tip of South America while zonal wind prevailed over Patagonia (defined as the continental region south of $40^{\circ} \mathrm{S}$ ). At subtropical latitudes the South Pacific anticyclone was slightly stronger than 


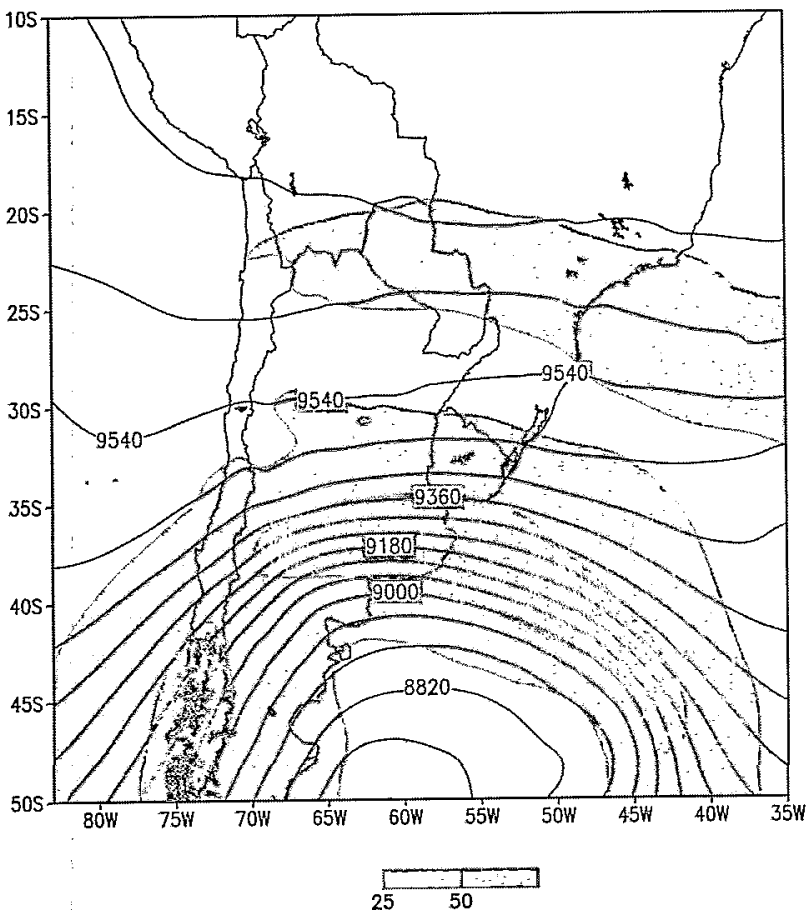

FIG. 3. NCEP-NCAR reanalyzed geopotential height (solid lines, contoured every $90 \mathrm{~m}$ ) and wind velocity $\left(\mathrm{m} \mathrm{s}^{-1}\right.$; values higher than $25 \mathrm{~m} \mathrm{~s}^{-1}$ are shaded) at the $300-\mathrm{hPa}$ level at 1200 UTC 15 Apr 1999.

average [compared to the monthly long-term mean obtained from the National Centers for Environmental Prediction-National Center for Atmospheric Research (NCEP-NCAR) reanalysis] and over the continent an incipient thermal-orographic low seated over northwestern Argentina near $27^{\circ} \mathrm{S}$. During 14 April (Fig. 2b), the cold front moved equatorward reaching northern Patagonia $\left(40^{\circ} \mathrm{S}\right)$, in connection with a deepening surface low over the South Atlantic and a pronounced trough at midlevels. To the north of the surface front, satellite imagery (not shown) reveals orographic clouds typical of zonda winds aloft (Norte 1988; Seluchi et al. 2003a). At the same time, the thermal-orographic low east of the Andes was deepening, accelerating northerly winds over north-central Argentina, Uruguay, and southern Brazil.

On 15 April, the active cold front reached northern Argentina, region favored for cyclone development over the southwestern Atlantic. The stations in northcentral Chile show little (if any) meridional thermal gradient or wind shift, so the front is hardly discernible to the west of the Andes. By 1200 UTC (Fig. 2c) the cold core, postfrontal anticyclone moved into the continent around $42^{\circ} \mathrm{S}$. Note the cyclonic curvature of the isobars over the Andes, indicative of a restricted displacement of the anticyclone over this region. The sub-

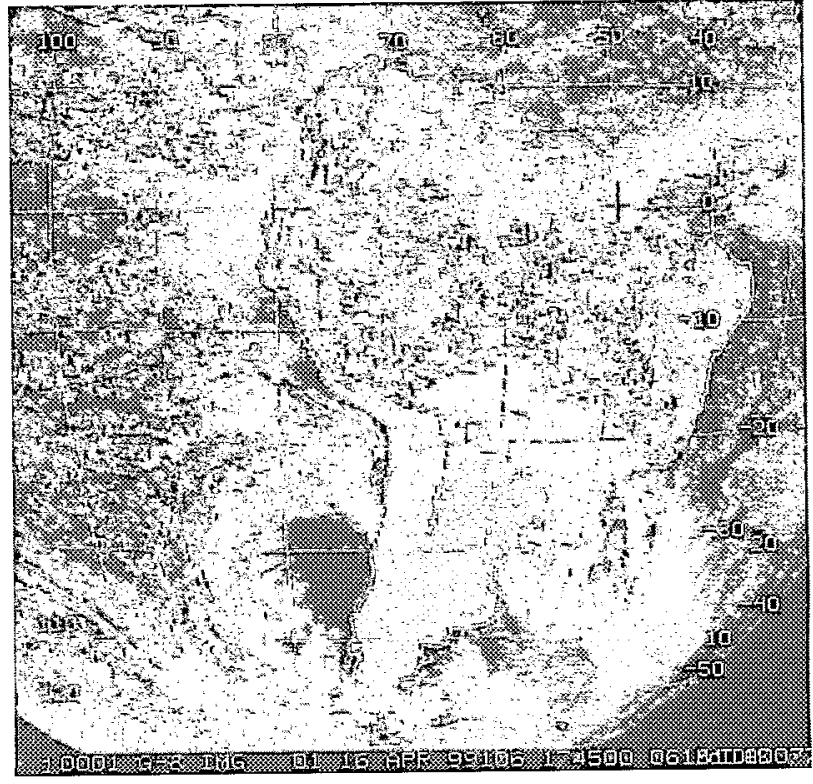

FIG. 4. GOES-8 visible (channel 1) satellite image at 1745 UTC 16 Apr 1999.

sequent advance of the cold air overrode the thermalorographic low east of the Andes. At mid- and upper levels the axis of the trough moved into the Atlantic sea border, while the axis of the ridge was still off the $\mathrm{Pa}$ cific coast. In between, strong southerly winds at 300 hPa over Patagonia are detected (Fig. 3). Vera and Vigliarolo (2000) show that the upper-level southerlies over Patagonia are more intense in those cases that produce frost events in subtropical regions.

During 16 April (Fig. 2d) the pressure begins to drop to the west of the subtropical Andes, leading to the formation of a coastal depression, an increase in air temperature, and the occurrence of low-level easterly flow. The subsidence warming also produces a clearing of the stratocumulus off of central Chile (Fig. 4). Farther north along the western side of the Andes conditions remain mostly invariant. On the eastern side of the mountains, the active cold front has advanced farther north of the tropic of Capricorn, reaching central Bolivia and southern Brazil (around $15^{\circ} \mathrm{S}$; see also Fig. 4) and freezing conditions were observed in central Argentina. The coastal low to the west and the intense anticyclone to the east produce an east-west surface pressure difference of almost $30 \mathrm{hPa}$ across the subtropical Andes.

Finally, during 17 April the cold front tends to become stationary over southwestern Amazonia (not shown). In the next 24-48 h the cold anticyclone (weakened at this time) moved eastward merging with the South Atlantic subtropical anticyclone (Dallavalle and Bosart 1975). 


\section{Model description and methodology}

To obtain a synoptic and subsynoptic description of the structural evolution of the cold front as it crossed the Andes, a numerical simulation of the episode was performed using the Eta Model version used in the Brazilian Center for Weather Forecasts and Climate Studies (CPTEC). The Eta-CPTEC is a regional model that uses the eta $(\eta)$ vertical coordinate, defined by Mesinger (1984), in order to improve the calculation of horizontal magnitudes over sharp topography. The $\eta$ surfaces are practically horizontal even on mountain slopes, allowing a better representation of the horizontal variations of the atmospheric parameters in the presence of sharp topography (Mesinger and Black 1992). Even thought the Eta Model evidenced some failure to generate downslope wind storms in regions of complex terrain (information online at http://meted. ucar.edu/nwppcu2/etvcoor1.htm), the Eta-CPTEC model showed satisfactory results in the Andes region (Seluchi et al. 2003a). The prognostic variables are temperature, specific humidity, winds, surface pressure, turbulent kinetic energy, and cloud water. The equations are solved on the Arakawa $\mathrm{E}$ grid and integrated through a split-explicit scheme based on forwardbackward and Euler-backward schemes, both modified by Janjić (1979). The Eta-CPTEC regional model has been operationally used at CPTEC to provide weather forecasts over most of South America since late 1996.

The Eta-CPTEC was run with 40-km horizontal grid spacing and 38 vertical layers with the model top placed at the 25-hPa level. The model includes a complete physics package with the Betts and Miller (1986) scheme for convective precipitation modified by Janjić (1994) and large-scale precipitation solved in an explicit way (Zhao and Carr 1997). Turbulent fluxes are represented through an updated Mellor and Yamada 2.5order scheme. Surface heat and humidity fluxes are solved using the Monin-Obukov scheme, whereas the radiation package for both short- and longwave radiation was developed at the Geophysical Fluid Dynamics Laboratory (GFDL) (Lacis and Hansen 1974; Fels and Schwarzkopf 1975). The soil scheme used in the current version of the Eta-CPTEC is the Oregon State University (OSU; Chen et al. 1996) model that includes three subsuperficial layers and another in which vegetation canopy is simulated. For more details on the model physics, see Black (1994).

Initial and boundary conditions were provided by the NCEP operational analyses every $6 \mathrm{~h}$ for this simulation experiment with a horizontal resolution of approximately $93 \mathrm{~km}$ (T126 triangular truncation) and 28 ver-

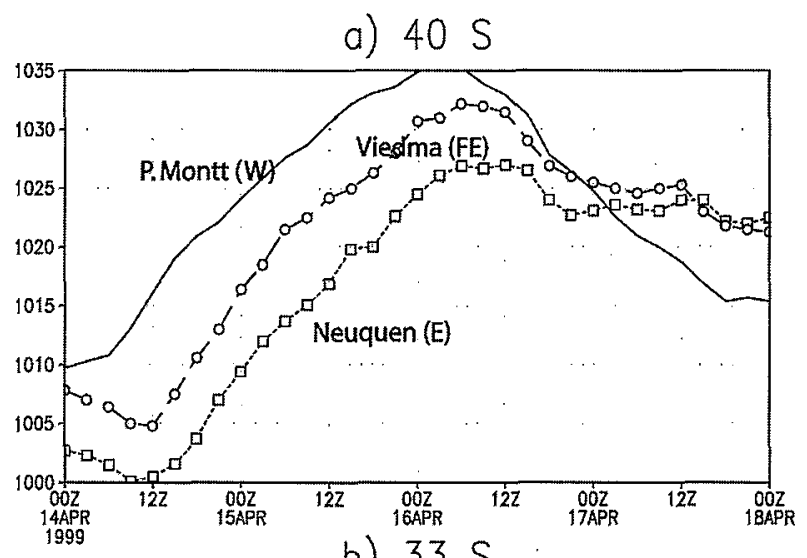

b) $33 \mathrm{~s}$
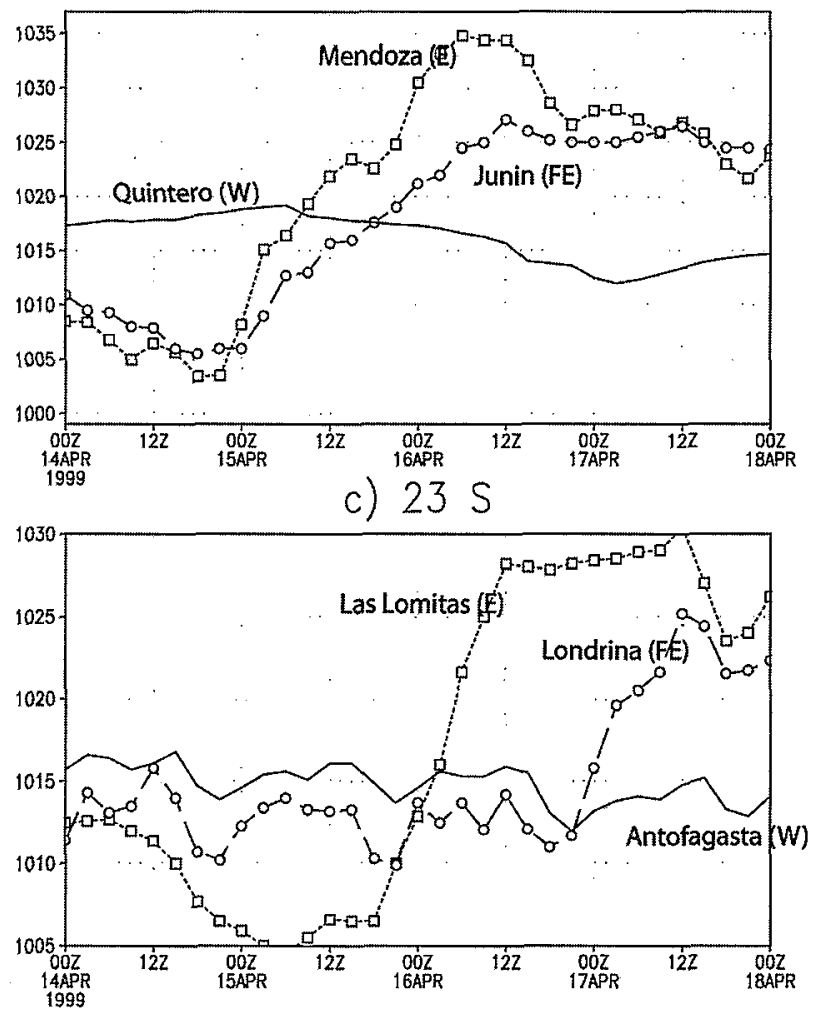

FIG. 5. Time evolution of sea level pressure (hPa) observed at (a) Puerto Montt (solid line), Neuquen (dashed line with boxes), and Viedma (dotted line with circles), (b) Quintero (solid line), Mendoza (dashed line with boxes), and Junin (dotted line with circles), and (c) Antofagasta (solid line), Las Lomitas (dashed line with boxes), and Londrina (dotted line with circles). The band of longitude in which the stations are located is indicated at the top of each panel. See also Fig. 1 for station locations. Symbols indicate each station's position relative to the Andes: W, west of the Andes; E, east of the Andes; and FE, far east of the Andes.

tical levels. The annual climatology of soil moisture, seasonal fields of albedo, and observed weekly mean sea surface temperatures are used as initial lower boundary conditions. The model domain and numerical settings are the same as those implemented in the operational version (Seluchi and Chou 2001). The simu- 
a) $40 \mathrm{~S}$

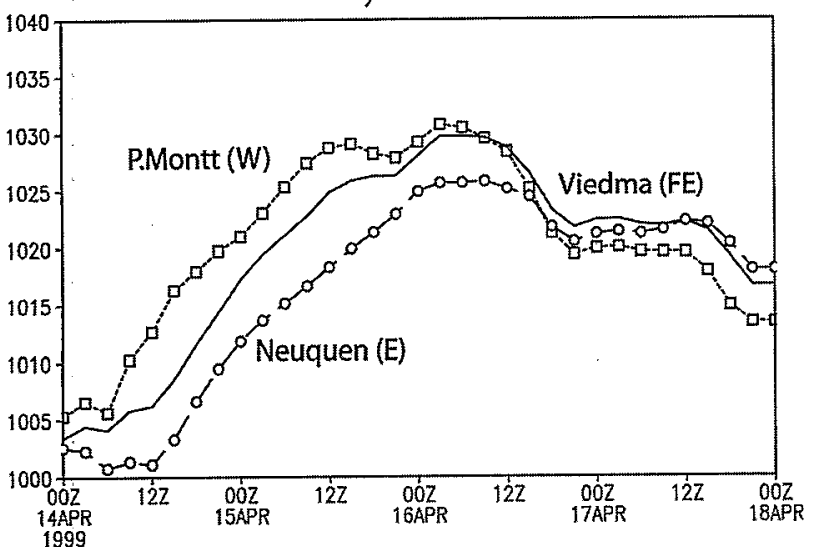

b) $33 \mathrm{~s}$
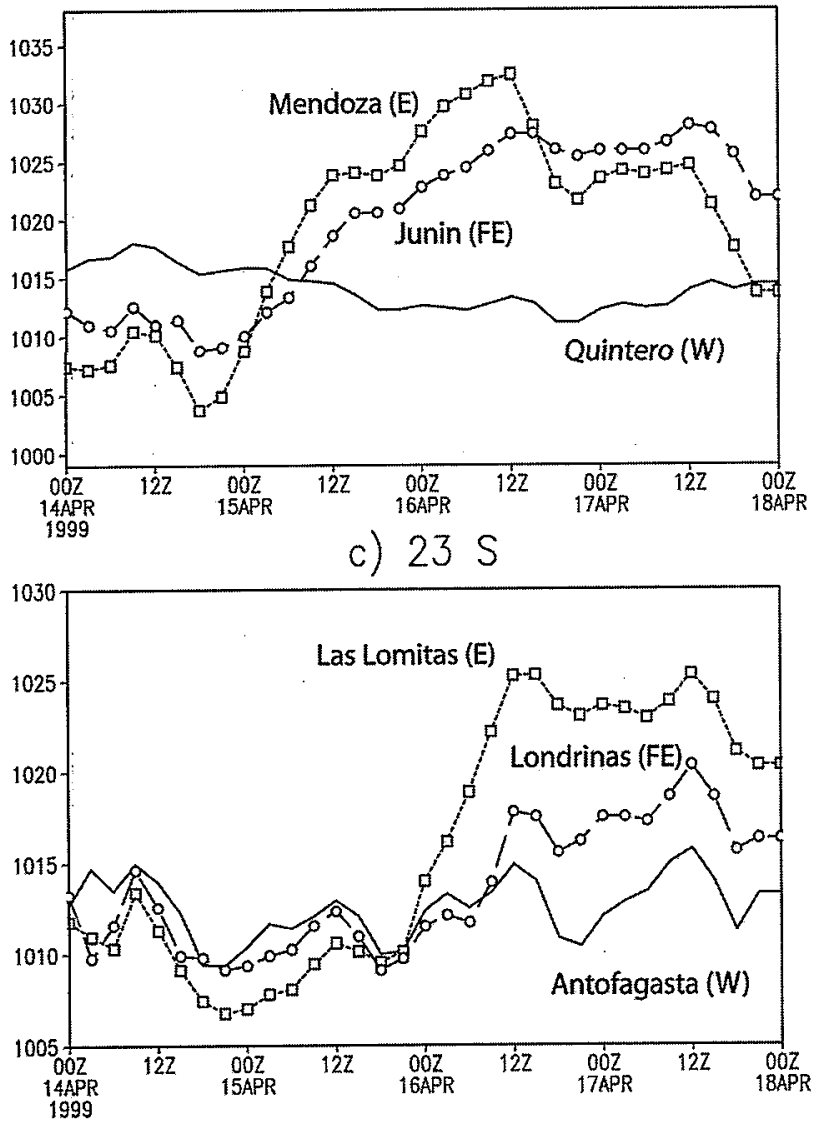

FIG. 6. Time evolution of the simulated sea level pressure ( $\mathrm{hPa}$ ) for the grid points closest to the stations used in Fig. 5 and using the same bands of latitude.

lätion length was set as $96 \mathrm{~h}$, extending from 0000 UTC 14 April through 0000 UTC 18 April. Simulated fields were saved every $3 \mathrm{~h}$.

To facilitate the analysis of the physical processes that played a part in the frontal propagation, the simulation was divided in two periods. The "active" period was defined as being from the beginning of the simulation (0000 UTC 14 April) to the moment when the

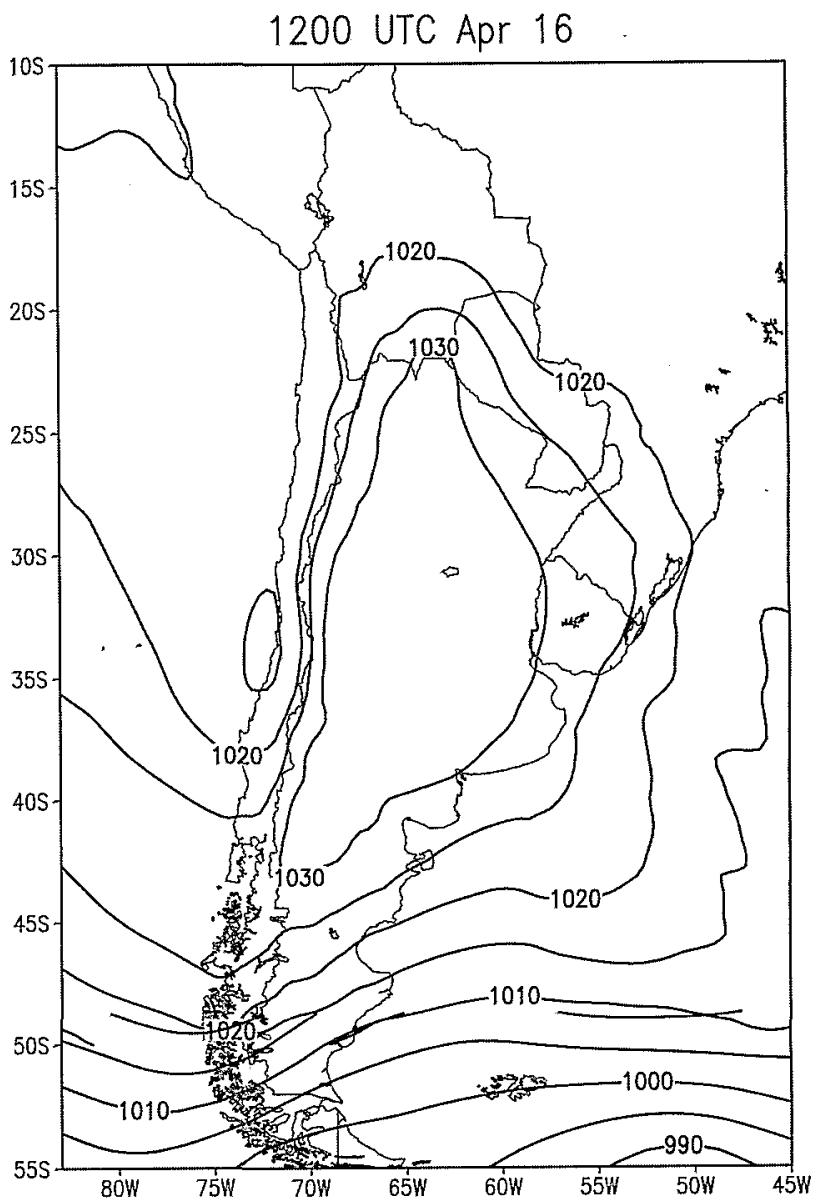

FIG. 7. Sea level pressure (solid lines, contoured every $5 \mathrm{hPa}$ ) as simulated by the Eta-CPTEC model valid for 1200 UTC 16 Apr 1999 (60-h simulation).

front became stationary at subtropical latitudes, approximately at 0000 UTC 17 April. The "demise" period extends from that time until the end of the simulation (0000 UTC 18 April).

Of particular interest for our analysis is the thermodynamic equation, which in $\eta$ vertical coordinates is written as

$$
\frac{\partial T}{\partial t}=-\mathbf{V} \cdot \nabla_{\eta} T-\dot{\eta} \frac{\partial T}{\partial \eta}+\frac{\chi T \omega}{p}+\frac{\dot{Q}}{C_{P}},
$$

where $T$ is the temperature, $\mathbf{V}$ is the horizontal wind vector, $\omega$ is the vertical velocity in pressure coordinates, $\chi$ is $\mathrm{R}\left(\mathrm{c}_{\mathrm{p}}\right)^{-1}$; $\dot{\eta}$ is the vertical velocity in $\eta$ coordinates, and $\dot{Q} / C_{p}$ represents diabatic sources/sinks.

Proper treatment of each individual term allowed a quantitative assessment of the relative contribution of each process relevant in the simulated temperature changes. The second and third terms in the rhs of (1) will be handled together, since they are due to adiabatic ascents and or descents, and will be referred to as the "static stability" term (e.g., Bluestein 1993). The dia- 

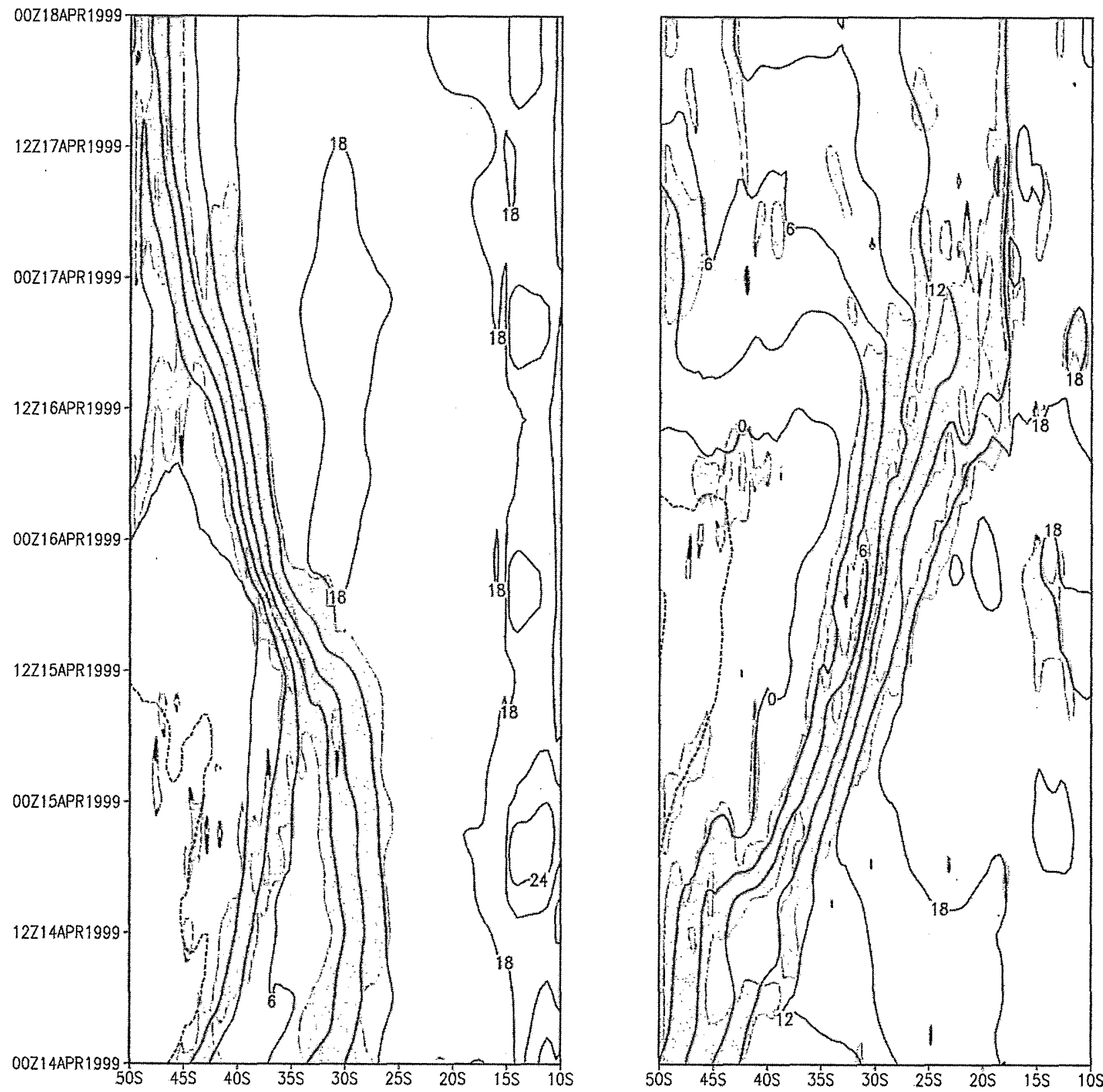

FIG. 8. Latitude-time cross section of the $850-\mathrm{hPa}$ air temperature contoured every $3^{\circ} \mathrm{C}$ along (a) $75^{\circ}$ and (b) $65^{\circ} \mathrm{W}$. Light (dark) shading indicates periods when $\left|\nabla_{p} T\right|>2 \mathrm{~K}(100 \mathrm{~km})^{-1}\left[4 \mathrm{~K}(100 \mathrm{~km})^{-1}\right]$.

batic source/sink term will be split into three main contributions: (a) "moisture processes," which include warming/cooling due to large-scale condensationevaporation and cumulus convection, (b) "radiation," which takes into account the temperature changes associated with radiative transfers in the atmosphere, and (c) "surface processes," which are derived from surface fluxes. This selection of terms was preferred since some processes involved are essentially similar and/or because a detailed examination of their differences is beyond the scope of this paper (e.g., the relative contribution of large-scale condensation versus that coming from cumulus convection). Also, when the relative contribution of a process is not significant, as happens with diffusive terms, it will not be included in the discussion. Accordingly, the thermodynamic equation is schematically represented as the sum of horizontal advection, static stability, moisture processes, radiation, and surface processes. Each one of the terms in Eq. (1) has been quantified directly form the model code. The resulting three-dimensional grid outputs were stored at each model time step (96 s) in order to avoid computational residuals. Values were plotted at 3 -h intervals. Colle and Mass (1995) also evaluated the thermody- 
1200 UTC 15 April $1999-63 W$

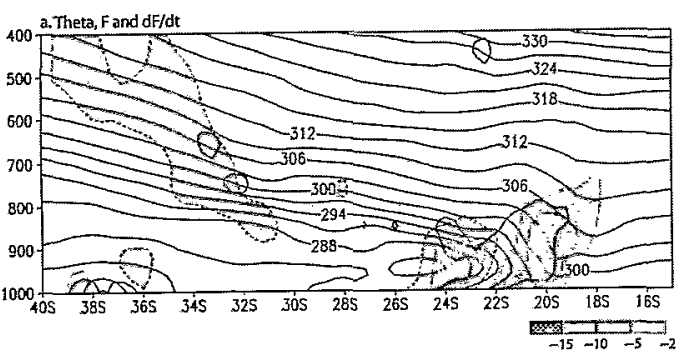

b. F and meridional wind
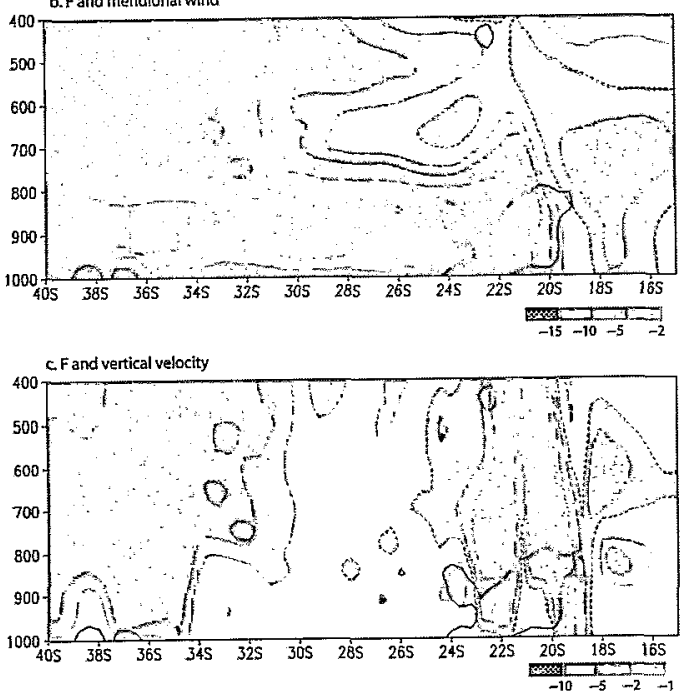

0900 UTC 16 April 1999 - 63W
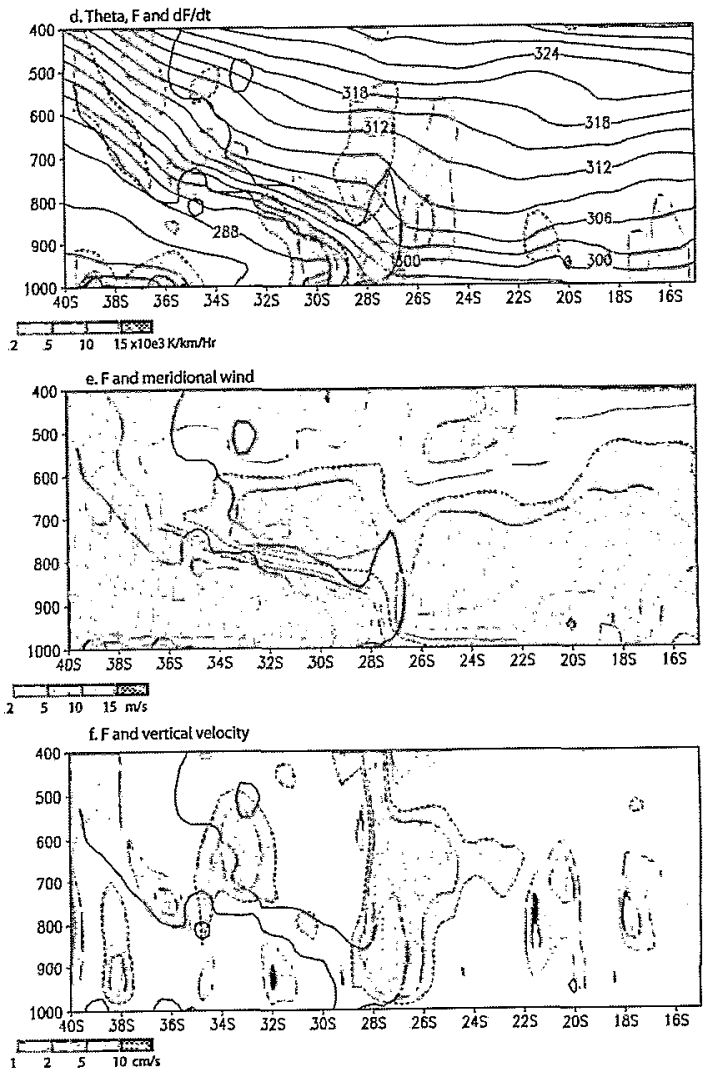

FIG. 9. Pressure-latitude cross section along $63^{\circ} \mathrm{W}$ (to the east of the Andes) for several variables related to frontal evolution: (a)-(c) 1200 UTC 15 Apr and (d)-(f) 1200 UTC 16 Apr 1999. (top) The potential temperature (thin, black contours, every $3 \mathrm{~K}$ ), the baroclinic zone (thick red line) defined as $F=\left|\nabla_{p} \theta\right|>3 \mathrm{~K}(100 \mathrm{~km})^{-1}$, and the local rate of change of $F$ (shading according to scale at bottom). (middle) The baroclinic zone (thick black line) and meridional wind speed (shading according to scale at bottom). (bottom) The baroclinic zone (thick black line) and vertical wind (shading according to scale at bottom). (g)-(i) As in previous panels but for a cross section at $76^{\circ} \mathrm{W}$ (to the west of the Andes) at 2100 UTC $15 \mathrm{Apr} 1999$.

namic budget during the evolution of a cold surge over North America using a sigma coordinate regional model but ignoring diabatic effects and vertical advection. Konrad and Colucci (1989) applied a similar methodology to the NCEP-NCAR reanalyses at the $850-\mathrm{hPa}$ level in order to analyze two polar outbreaks over North America. In South America, Garreaud (1999) and Garreaud and Rutllant (2003) present a crude evaluation of the thermodynamic energy equation at the $925-\mathrm{hPa}$ level using fifth-generation Pennsylvania State University-National Center for Atmospheric Research Mesoscale Model (MM5) results for a cold surge and coastal low event, respectively.

\section{Results}

\section{a. Model validation}

Figure 5 shows the evolution of the surface pressure recorded at nine stations located at both sides of the
Andes (see Fig. 1). At midlatitudes (Fig. 5a) the pressure follows a similar trend on both sides, characterized by a sustained increase from the passage of the surface front up to a nearly simultaneous maximum during 16 April associated with the center of the postfrontal anticyclone. In contrast, significant differences across the mountain are found at subtropical latitudes (Fig. 5b). A weak maximum in Quintero (west side) occurs at the beginning of 15 April, followed by a gentle decrease that indicates the development of the coastal low in central Chile. On the other side of the mountains the pressure experiences a marked increase during 15 and 16 April, particularly in Mendoza, the station closest to the Andes. At tropical latitudes (Fig. 5c) the surface pressure on the west side (Antofagasta) remains nearly invariant during this period, while the surface pressure near the eastern slope of the Andes (Las Lomitas) exhibits a pronounced increase during 16 April, remaining high during most of 17 April. In Londrina, located 
2100 UTC 15 April 1999 - 76W
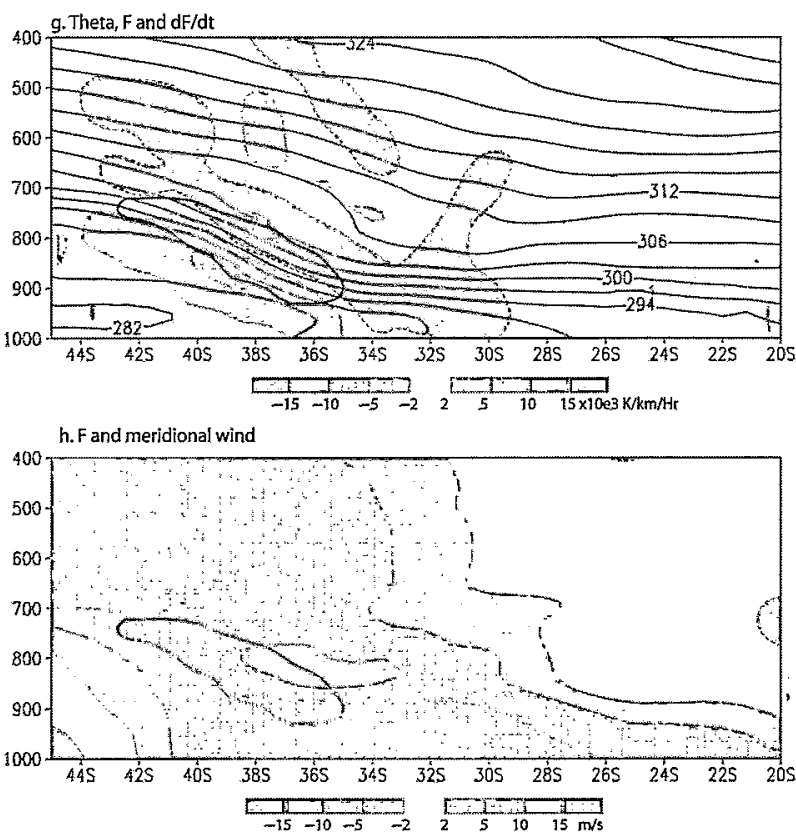

i. F and vertical velocity

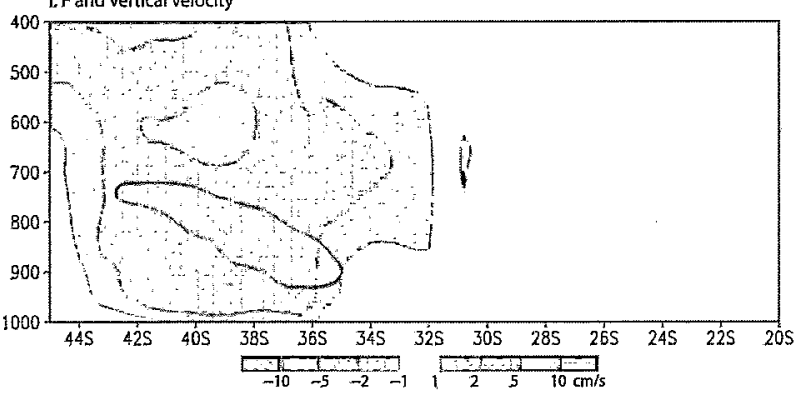

FIG. 9. (Continued)

farther east, the pressure increases less than and at a later time that at Las Lomitas.

For comparison, Fig. 6 includes the simulated time series of the surface pressure at the grid points closest to the stations used in Fig. 5. To the east of the Andes the model tends to overestimate the maximum in surface pressure associated with the postfrontal anticyclone by as much as $5 \mathrm{hPa}$, while to the west of the subtropical Andes $\left(33^{\circ} \mathrm{S}\right)$ the simulated minimum associated with the coastal low is $\sim 2 \mathrm{hPa}$ weaker than its observational counterpart. Despite these problems, the model was able to capture quite well the differential evolution of the surface pressure at tropical and subtropical latitudes, and the more similar evolution in midlatitudes, lending support to the use of model outputs to further describe and diagnose this event. Moreover, the simulated spatial structure of the surface pressure field near the time of maximum pressure gradient across the subtropical Andes agrees well with the manual analysis (cf. Fig. 7 and Fig. 2d), but for a more poleward positioning of the coastal low and the wider cold core anticyclone.

\section{b. Frontal evolution}

The trace of the cold front using maps of modelderived low-level air temperature is qualitatively similar to the hand-made analysis shown in Fig. 2. The most striking feature is the differential advance of the front at each side of the Andes, illustrated in Fig. 8 by a time-latitude cross section of the 850 -hPa air temperature along $76^{\circ} \mathrm{W}$ (over the Pacific Ocean) and $60^{\circ} \mathrm{W}$ (over the continent, to the east of the Andes). Over the continent to the east of the Andes, the cold air advances equatorward rather continuously at about 10 $\mathrm{m} \mathrm{s}^{-1}$ from 14 until 17 April, when the cold front becomes stationary at $15^{\circ} \mathrm{S}$. In this region the front is almost completely aligned along the $x$ axis (except very close to the Andes slope or near the sea border), so that $|\nabla \theta| \sim|\partial \theta / \partial y|$. This meridional gradient is superimposed onto Fig. 8, and indicates frontogenesis from the beginning of the simulation until about 1800 UTC 15 April, when the front was at $28^{\circ}-30^{\circ} \mathrm{S}$, follow by frontolysis during 16 and 17 April. The mostly zonal orientation of the front allows us to use the following twodimensional frontogenesis function (e.g., Bluestein 1993, section 2.3.1):

$$
\begin{aligned}
F= & \frac{d}{d t}|\nabla \theta|=\frac{d}{d t}\left|\frac{\partial \theta}{\partial y}\right|=\frac{\partial v}{\partial y} \cdot \frac{\partial \theta}{\partial y}+\frac{\partial w}{\partial y} \cdot \frac{\partial \theta}{\partial p} \\
& -\frac{1}{C_{P}}\left(\frac{p_{0}}{p}\right)^{k} \frac{\partial}{\partial y}\left(\frac{d Q}{d t}\right),
\end{aligned}
$$

where all the partial $y$ derivatives are taken at a constant pressure level. Figure 9a includes pressurelatitude cross sections along $63^{\circ} \mathrm{W}$ of several variables that are key to evaluating the right-hand side of Eq. (2), near the time of the front's maximum strength. At this time the front (identified as the warm boundary of the maximum baroclinicity zone) extends from the surface well into the middle troposphere. Below $850 \mathrm{hPa}$ there is a strong couplet of the local rate of change of the $|\partial \theta / \partial y|$, consistent with the equatorward advance of the front. Furthermore, the frontogenesis is readily apparent at this time, as the meridional temperature gradient is increasing within the frontal zone. The main forcing of the frontogenesis is the confluence of the meridional wind. In the lower troposphere, the meridional wind changes from southward to northward right at the front, thus cooling the cold side and warming the warm side of the front. In this panel it is also evident that strong southerlies at low levels move into subtropical latitudes well before the southerlies aloft. The tilting term has a 
frontolysis effect, since at this time most of the ascent (and hence cooling) takes place over the warm side of the frontal zone. While low- and midlevel clouds blanket the cold air dome, their frontogenetical effect has secondary importance because the variation of the surface and radiative fluxes across the front are not too large (a few tenths of a Watt per meter squared) and diluted on a relatively deep layer.

The same panels/variables along $63^{\circ} \mathrm{W}$ are shown in Fig. $9 \mathrm{~b}$ when the front has reached $20^{\circ} \mathrm{S}$. At this time the cold air dome continues moving equatorward, but it is largely restricted to below $800 \mathrm{hPa}$, so that the front is only identified in the lower troposphere. There is weak frontogenesis (frontolysis) on the warm (cold) side of the baroclinic zone; integrated across the baroclinic zone, frontolysis prevails. The main difference from the situation before is that the poleward wind (ahead of the front) over the northern portion of the domain is very weak, thus strongly reducing the frontogenetic role of the meridional confluence. Note also that ascending motion is now also occurring over the cold side of the front, but mostly above $800 \mathrm{hPa}$ and, as we show later, it is largely compensated for by the latent; heat release and, thus, is not too efficient as a frontogenetic effect.

The cold air at $850 \mathrm{hPa}$ to the west of the Andes (Fig. 8a) moves equatorward until 1200 UTC 15 April, and much slower than its counterpart to the east, so the cold front at this level reaches to only $35^{\circ} \mathrm{S}$. Before 1200 UTC 15 April there are two regions of maximum baroclinicity: one associated with the migratory cold front, and the other quasi stationary at $30^{\circ} \mathrm{S}$. This later region is present at initialization and is presumably associated with the subsidence inversion of the subtropical anticyclone of the Pacific Ocean that slopes northward, and is not related to the front analyzed in this work. By 1200 UTC 15 March both baroclinic zones have merged and begun to move poleward in response to the marked warming at subtropical latitudes. Thus, the baroclinc zone to the west of the Andes is better described as a warm front during its mature stage. There is frontogenesis only during the second half of 15 April. Again, a qualitatively understanding of the leading processes behind the front evolution can be obtained from the pressure-latitude cross section of the relevant variables along $76^{\circ} \mathrm{W}$ (Fig. 9c). In this case, because subsidence prevails in the lower and middle troposphere, warming the cold (warm) air below (above) the front, its net effect on the front intensity is near zero. The horizontal term produces frontolysis as a southerly jet appears well to the north of the jet, thus causing diffluence over the frontal zone.

\section{c. Thermodynamic analysis}

The determination of the leading thermodynamics processes is crucial to understand the physical mechanisms that control the evolution of the cold front. This technique allows us to explain the physical processes responsible for local temperature changes (related to the frontal track) and indirectly for the front intensification-decay. Furthermore, as suggested by the longitude-pressure cross section of the temperature and geopotential changes during the active period taken at $30^{\circ} \mathrm{S}$ (Fig. 10), and confirmed by the hypsometric equation, surface pressure changes (and hence winds) are mostly hydrostatically driven by low-level (1000-700 $\mathrm{hPa}$ ) air temperature changes over most of the domain.

Figure 11 shows the temperature tendencies vertically integrated in the layer 1000-700-hPa layer associated with each of the terms of the thermodynamic equation (see section 3) during the active period. A zonal band of cold advection is found over the continent between $33^{\circ}$ and $42^{\circ} \mathrm{S}$ (Fig. 11a), with similar values on each side of the Andes, in connection with southerly winds behind the cold front. A northward extension of the area of cold advection (to the north of $30^{\circ} \mathrm{S}$ ) is found immediately to the east of the Andes and is presumably associated with southerly winds that flow toward the warm core northwestern Argentinean low (Seluchi et al. 2003b) before the frontal passage, and with the subsequent fast northward propagation of the anticyclonic anomaly due to the interaction between the synoptic wave and the orography (Gan and Rao 1994; Seluchi et al. 1998; Vera and Vigliarolo 2000).

In contrast with the horizontal advection term, the static stability (vertical) term exhibits a pronounced difference across the mountains (Fig. 11b). Ascending motion leads to negative temperature tendencies along the surface front (Paraguay, southern Brazil, and the southeast Atlantic) and along the eastern slope of the subtropical Andes. To the south of $30^{\circ} \mathrm{S}$, synoptic-scale subsidence over the postfrontal anticyclone produces positive temperature tendencies over the continent and the adjacent Pacific Ocean, in agreement with Vera and Vigliarolo (2000) who analyzed a composite of anticyclonic situations evolving over southern South America. To the west of the Andes, however, the lowlevel warming is about three times larger than it is to the east.

Latent heat release over the frontal region leads to positive temperature tendencies (Fig. 11c) that are, however, mostly compensated for by the adiabatic cooling in the regions of ascending motion (cf. Figs. $11 \mathrm{~b}$ and 11c). The $1000-700-\mathrm{hPa}$ layer is cooled by radiative processes (Fig. 11d) and warmed by surface fluxes, es- 


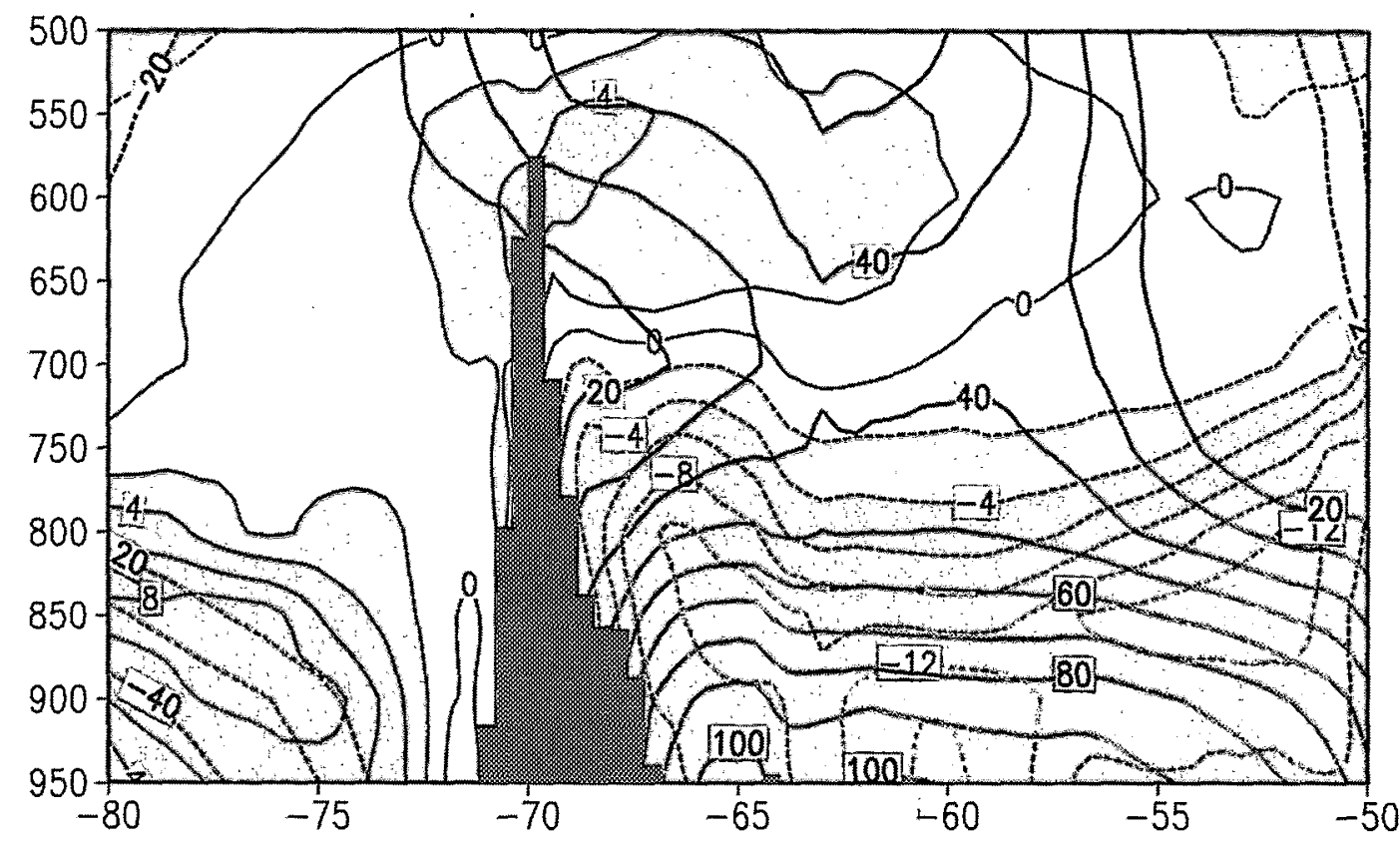

FIG. 10. Vertical cross section at $30^{\circ} \mathrm{S}$ of geopotential height change (contoured every $40 \mathrm{gpm}$ ) and temperature tendency ( ${ }^{\circ} \mathrm{C}$, shading) for the 1200 UTC 15 Apr-0000 UTC 17 Apr period. Model topographic profile is included.

pecially near the Andes slopes and to the south of $37^{\circ} \mathrm{S}$, where the cold core anticyclone moved over the warmer ocean.

Finally, Fig. 11f shows the sum of the temperature tendencies of each of the processes. Positive (negative) tendencies are found to the west (east) of the Andes due basically to the strong and differential effect of the static-stability term across the Andes superimposed upon the rather uniform horizontal cold advection. Qualitatively similar results are obtained if a shorter time period is used to construct Fig. 11. These results are also qualitatively similar to those reported by Garreaud (2000) and Garreaud and Rutllant (2003) for a cold surge and coastal low, respectively.

To further describe the mechanisms responsible for the temperature changes and the frontal displacement, Fig. 12 includes the leading terms of the thermodynamic equation expressed as the temporal evolution of the accumulated tendencies for six boxes across the domain (three on each side of the Andes as detailed in Fig. 11d). The total tendency in the two southernmost boxes $\left(37^{\circ}-42^{\circ} \mathrm{S}\right)$ exhibits a qualitatively similar behavior, but for their shift in time, with cooling from the beginning of the simulation and a subsequent warming due to vertical advection not compensated for by cold horizontal advection.

At subtropical latitudes $\left(30^{\circ}-35^{\circ} \mathrm{S}\right.$, middle panels in Fig. 12) and to the west of the Andes, warming prevails during the whole period, especially after 1200 UTC 15 April, driven by strong vertical warming that is nearly twice as large as the horizontal cold advection. To the east of the Andes, horizontal cold advection has a value similar to that to the west, but vertical advection is slightly negative, leading to a cooling tendency during most of the period. The tendency due to moist processes is very small, indicating that the cold front was devoid of significant low and middle clouds when it crossed this range of latitudes.

In the northernmost boxes $\left(20^{\circ}-25^{\circ} \mathrm{S}\right.$, bottom panels in Fig. 12), the temperature tendencies also differ markedly across the Andes. To the west, the total tendency is neglectible, with a nearly perfect balance between vertical warming and radiative cooling (as expected for a region covered by marine stratocumulus). To the east, the significant cooling begins at 0000 UTC 16 April, forced by both horizontal and vertical advection. The vertical advection is, however, mostly compensated for by the latent heat release in the cloudiness ahead and at the cold front, as corroborated by the satellite imagery shown in Fig. 4.

A thermodynamic analysis for the demise period (from 0000 UTC 17 April to 0000 UTC 18 April) is shown in Fig. 13. During this stage, horizontal cold advection behind the front extended as far north as $15^{\circ} \mathrm{S}$ (Fig. 13a). Neverthieless, over the Bolivian lowlands and western Brazil the warming due to subsidence (Fig. $13 \mathrm{~b}$ ), the radiation balance (Fig. 13c), and moist processes (not shown) offset the horizontal cold advection, leading to a slightly positive total temperature tendency (Fig. 13d). Farther south and over the subtropical At- 
(a) Horiz Adv.

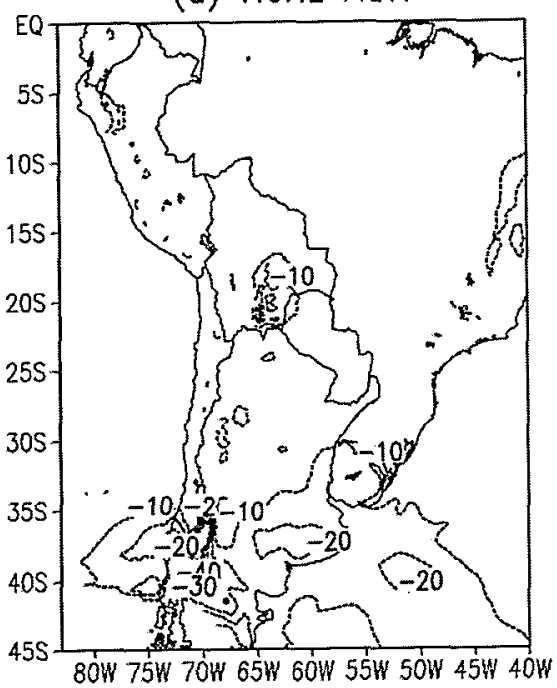

(c) Moist. Proc.

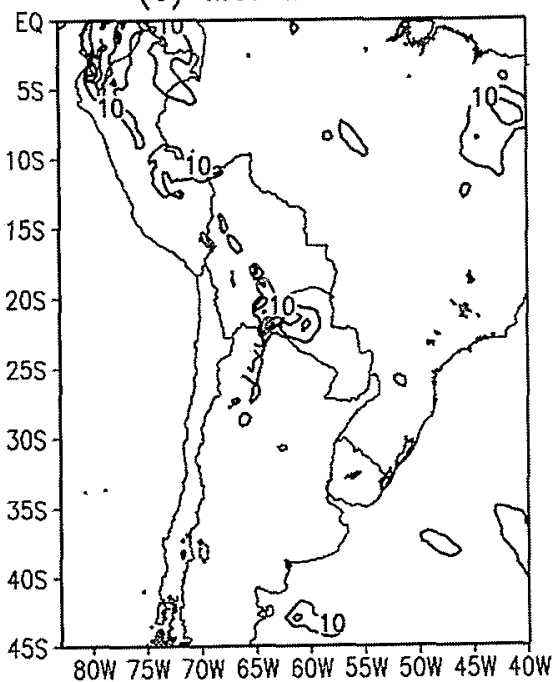

(e) Surface Proc.

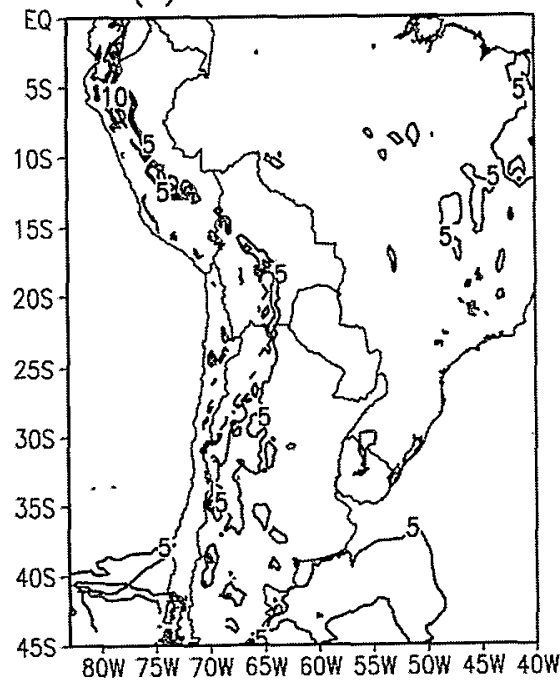

(b) Static Stab.

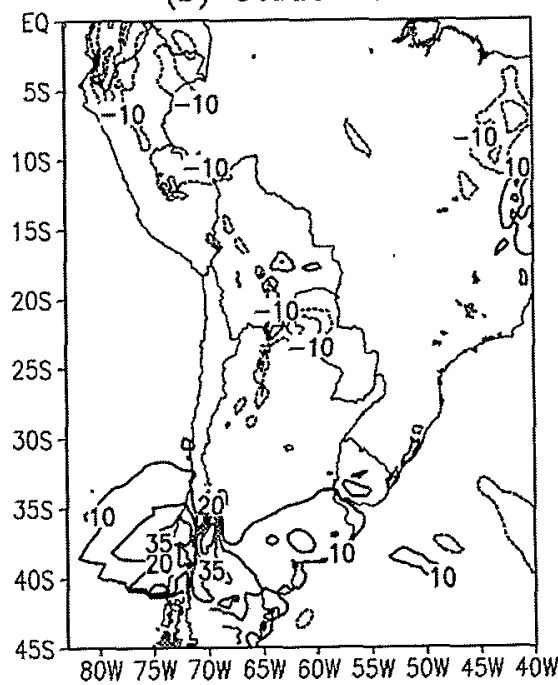

(d) Radiation

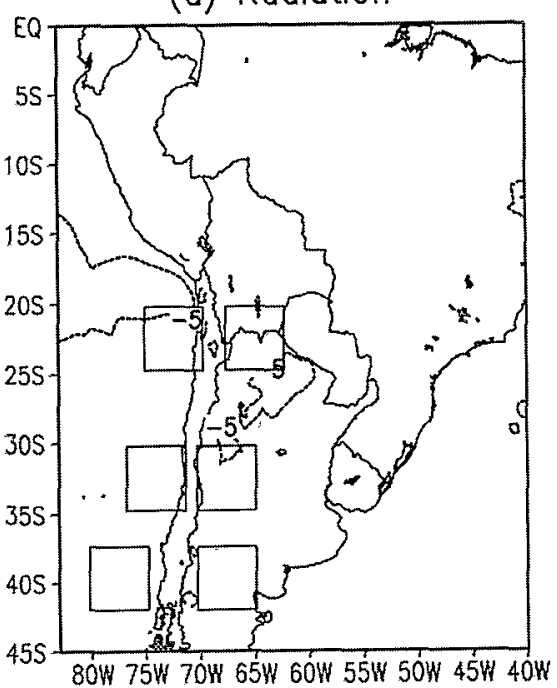

(f) All

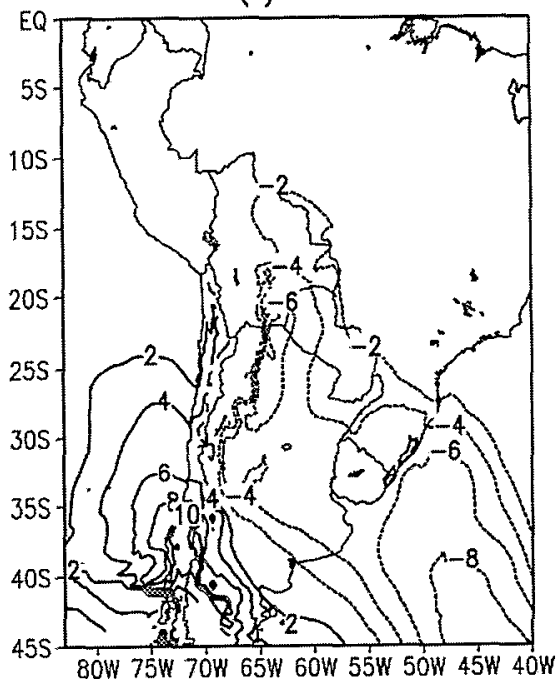


lantic ocean, cold advection still prevails but is largely compensated for by the postfrontal subsidence.

\section{d. Dynamical analysis}

To understand what causes the larger static-stability warming to the west of the Andes with respect to the east, Fig. 14 shows a longitude-height section along $33^{\circ}$ and $23^{\circ} \mathrm{S}$ of the vertical (omega) 'wind. Subsidence is found to the west of the Andes, and is especially strong at $33^{\circ} \mathrm{S}$, with a maximum between 900 and $700 \mathrm{hPa}$ very close to the mountain slope. Large-scale subsidence at midlevels is interrupted over the continent to the east of the subtropical Andes and reappears over the Atlantic. Ascending motion has a maximum very close to the eastern Andean slope at $23^{\circ} \mathrm{S}$, but is also present at $33^{\circ} \mathrm{S}$.

Figure 14 also shows the zonal wind component. Westerly flow prevails at upper and midlevels, being stronger at $33^{\circ} \mathrm{S}$ than at $23^{\circ} \mathrm{S}$ in response to the enhanced baroclinicity. In contrast, easterly flow dominates below $800 \mathrm{hPa}$ over the continent and the adjacent Pacific Ocean, driven by the postfrontal anticyclone centered farther south. The easterlies, however, exhibit a pronounced change in magnitude due to the barrier effects of the Andes Cordillera. The elevation of the Andes $(h \approx 4000 \mathrm{~m})$ and the strong stratification of the postfrontal air $\left(N \approx 1.8 \times 10^{-2} \mathrm{~s}^{-1}\right)$ are conducive to a strong blocking of the zonal flow, even for relatively strong winds [for instance, for $U=30 \mathrm{~m} \mathrm{~s}^{-1}$, the Froude number $[U /(N h)]$ is just 0.4$\}$. Not surprisingly, the zonal component of the wind becomes small $\left(|u|<5 \mathrm{~m} \mathrm{~s}^{-1}\right)$ near the eastern side of the subtropical Andes. This condition leads to the breakdown of the geostrophic balance, accelerating the southerly winds over central Argentina, as documented in Garreaud (1999).

There is an apparent contradiction between the blocking of the low-level flow to the east of the Andes and the adiabatic (upslope) cooling at the leading edge of the front. To clarify that point, we obtained parcel trajectories around the front based on consecutive model outputs (not shown). As expected, some air parcels ascended partly up the mountain slopes (up to about $2500 \mathrm{~m}$ ), before they were deflected eastward by the midlevel westerly flow. These parcels, however,
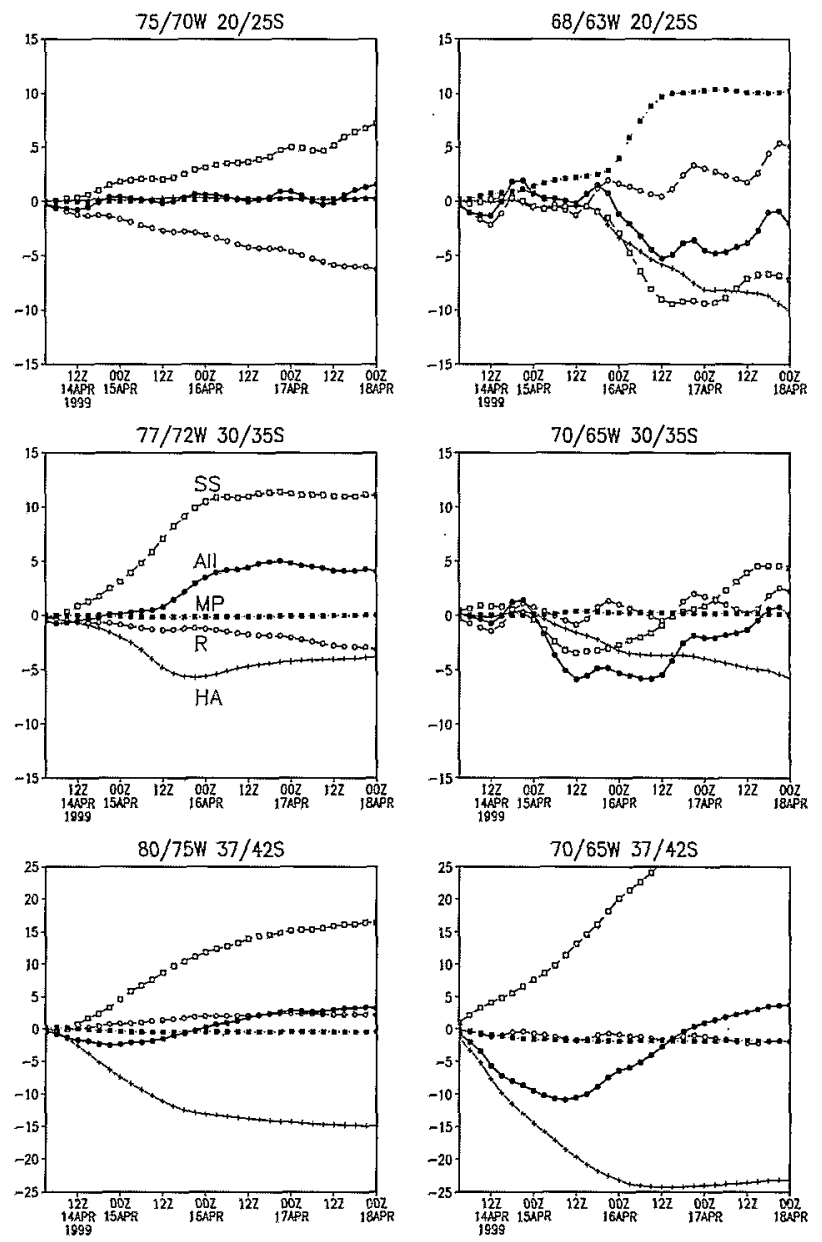

FIG. 12. Temporal evolution of the temperature tendency $\left({ }^{\circ} \mathrm{C}\right)$ integrated between the surface and 700-hPa levels associated with each of the terms of the thermodynamic equation in $\eta$ coordinates (Eta-CPTEC simulation) averaged over the indicated boxes (illustrated in Fig. 11d). Curves correspond to horizontal advection (HA, thin lines with vertical barbs), static stability (SS, dashed lines with open squares), radiation ( $R$, dashed lines with open circles), moist processes (MP, thin lines with solid squares), and the sum of all the process, as in Fig. 10f (all, thick lines with solid circles).

originated to the north of the front; air parcels originating to the south of the front subside as they move northward and away from the mountains.

Similarly, the steep western slope of the Andes restricts the low-level zonal flow in this region. For instance, in the zonal cross section $\left(33^{\circ} \mathrm{S}\right)$ in Fig. 14b, the

FIG. 11. Temperature tendency $\left({ }^{\circ} \mathrm{C}\right)$ averaged between the surface and $700-\mathrm{hPa}$ levels associated with each of the terms of the thermodynamic equation in $\eta$ coordinates (EtaCPTEC simulation) during the active period (0000 UTC 14 Apr-0000 UTC 17 Apr 1999). (f) The sum from (a) to (e). Boxes indicated in (d) were used to perform the temporal evolution shown in Fig. 12. 
(a) Horiz Adv.

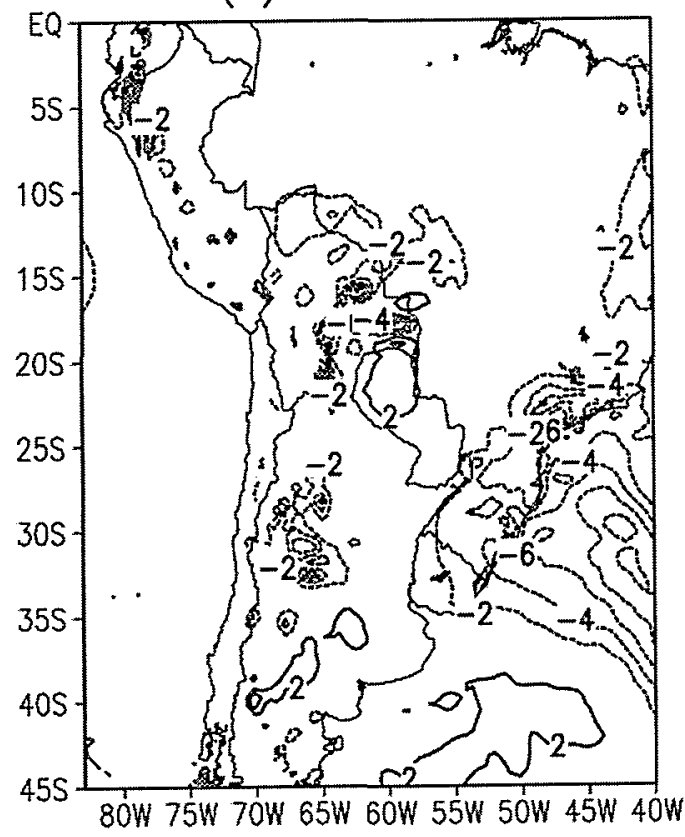

(c) Rad. + Surf. Proc.

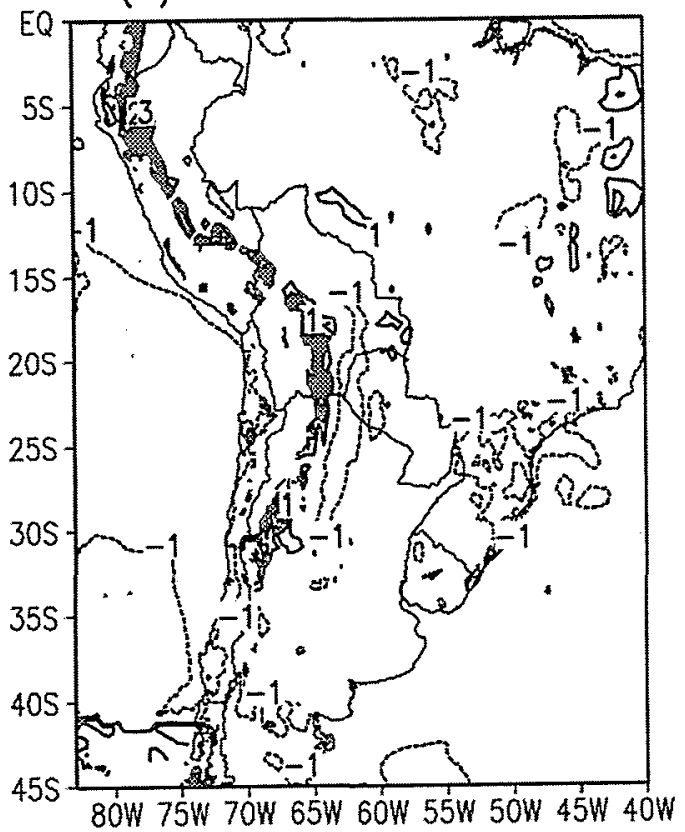

(b) Static Stab.

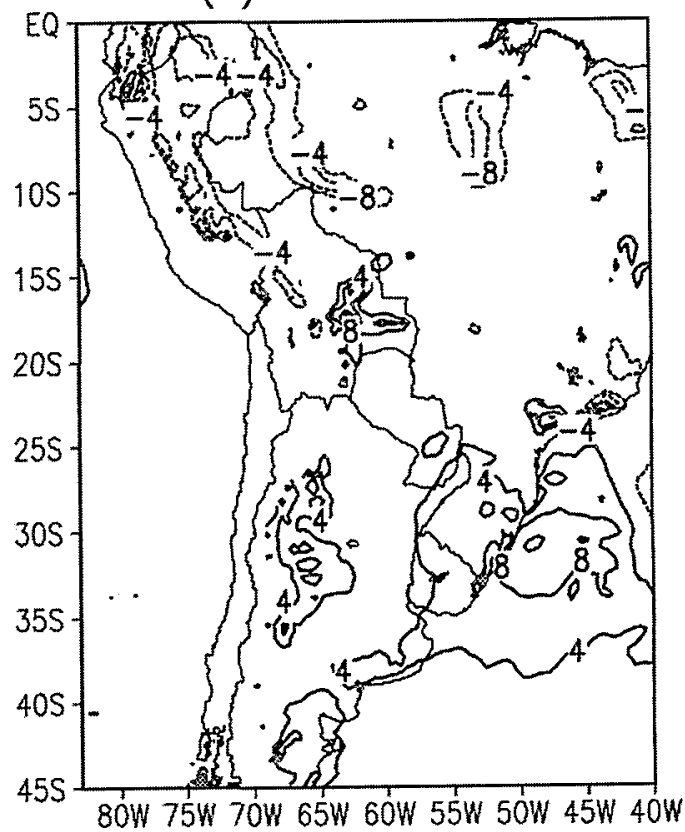

(d) All

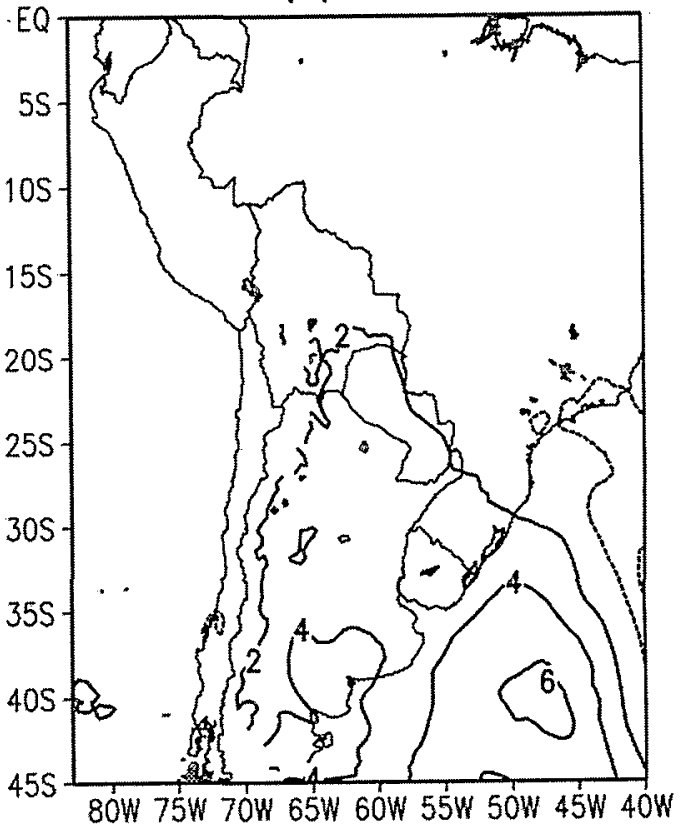

FIG. 13. As in Fig. 11 but for the decaying period (0000 UTC 17 Apr-0000 UTC 18 Apr 1999). Partial contribution of (a) horizontal advection, (b) static stability, (c) Radiation + surface processes, and (d) the sum of all the partial contributions (including those derived from moisture processes).

easterlies at $900 \mathrm{hPa}$ are near zero immediately to the west of the Andes but increase up to $6 \mathrm{~m} \mathrm{~s}^{-1}$ within 500 $\mathrm{km}$ off the coast (i.e., $\partial u / \partial x \approx+1 \times 10^{-5} \mathrm{~s}^{-1}$ ). Recently, Muñoz and Garreaud (2005) have shown that restriction of the zonal flow near the coast leads to the for- mation of a low-level, southerly coastal jet in this region. Downstream of the jet $\partial v / \partial y \approx+1 \times 10^{-5} \mathrm{~s}^{-1}$. Thus, the Andean topography leads directly to an offshore increase of the zonal wind and indirectly to the northward increase of the meridional wind, both con- 

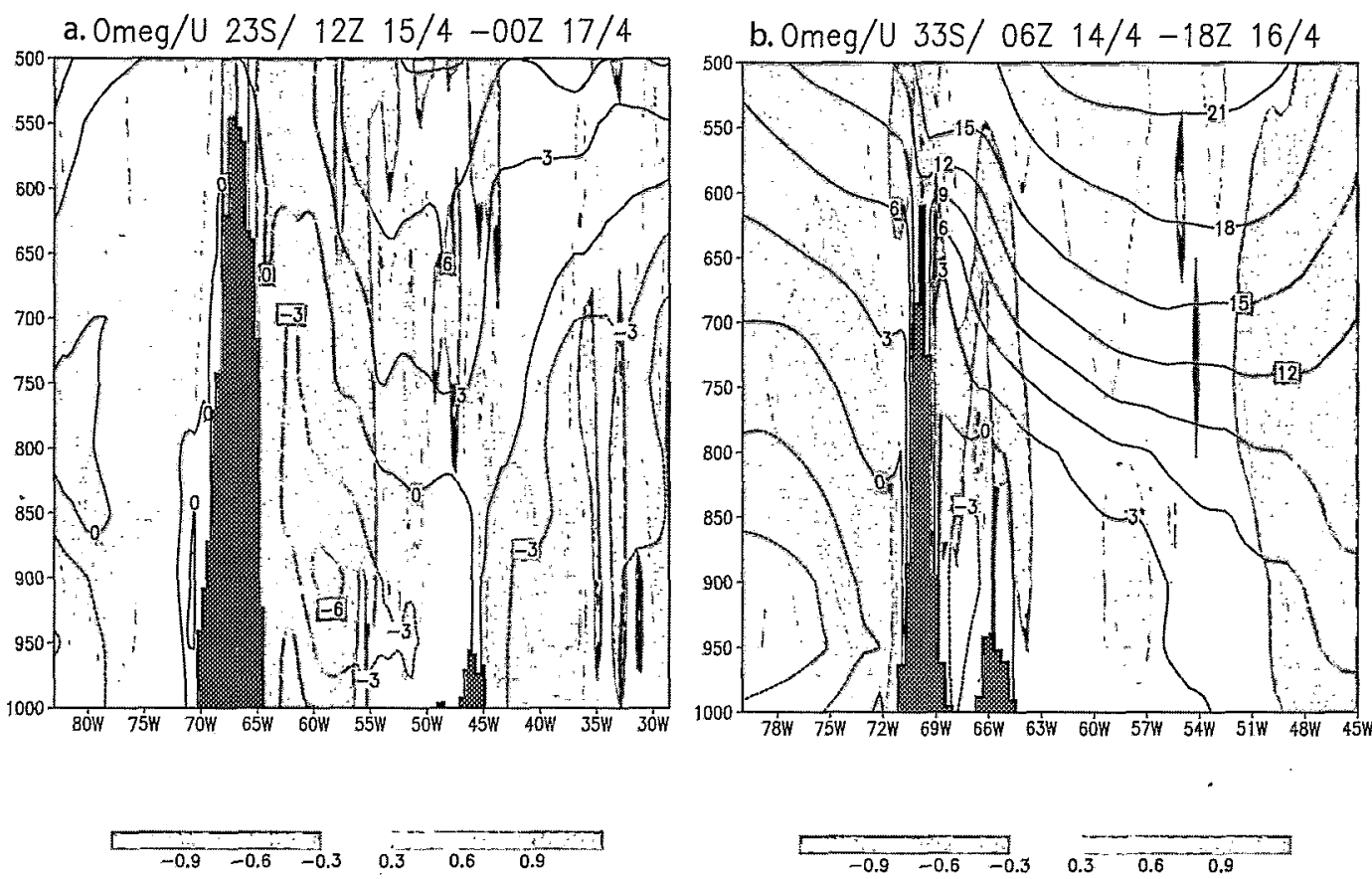

FIG. 14. Vertical cross section at (a) $23^{\circ}$ and (b) $33^{\circ} \mathrm{S}$ of the vertical omega (hPa s${ }^{-1}$, shaded) and zonal wind (contours, $\mathrm{m} \mathrm{s}^{-1}$ ) averaged between (a) 0000 UTC 14 Apr and 0000 UTC 17 Apr and (b) 0000 UTC 16 Apr and 0000 UTC 17 Apr 1999 from Eta-CPTEC simulations. Model topographic profile is included.

tributing to strong low-level divergence in the coastal region of south-central Chile, as shown in Fig. 15 by the ageostrophic wind and horizontal divergence at $850 \mathrm{hPa}$ at 0000 UTC 16 April. The strong low-level divergence in the coastal zone is compensated for by the enhanced subsidence. An order of magnitude for the vertical velocity can be obtained from the continuity equation: $W \approx H \nabla \cdot \mathbf{v}$, using $H \approx 1500 \mathrm{~m}$, and $\boldsymbol{\nabla} \cdot \mathbf{v} \approx+2 \times 10^{-5}$ $\mathrm{s}^{-1}, W \approx 3 \mathrm{~cm} \mathrm{~s}^{-1} \approx 0.3 \mathrm{hPa} \mathrm{s}^{-1}$, in close agreement with the values obtained in the simulation. The topographically enhanced subsidence takes places in a very stable environment, leading to strong warming of the lower and middle troposphere to the west of the subtropical Andes. The key role of the vertical motion on the warming to the west of the Andes can be visualized in the isochrones of $\theta=290 \mathrm{~K}$ on a pressure-latitude sections at $76^{\circ} \mathrm{W}$ (Fig. 16a) and contrasted by the more prominent role of the southerly winds to the east (Fig. 16b).

\section{Conclusions}

The Eta-CPTEC model was used to simulate and diagnose the passage of a cold front over southern South America, whose structural evolution is markedly influenced by the Andes Cordillera at subtropical latitudes. The event took placeiin mid-April 1999 and was selected because it exhibited many of the typical features of frontal passages in this region.
To the east side of the Andes, a dome of cold air between the surface and about $700 \mathrm{hPa}$ advanced well into the subtropical latitudes at about $10 \mathrm{~m} \mathrm{~s}^{-1}$, so the cold front could be traced up to about $15^{\circ} \mathrm{S}$. Associated with the postfrontal anticyclone, freezing conditions were observed on the morning of 16 April over central Argentina. In sharp contrast, the dome of cold ait becomes very shallow as it advances over the eastern $\mathrm{Pa}$ cific bounded by the western slope of the Andes. Even near the surface, the cold air reaches only up to $30^{\circ} \mathrm{S}$. At subtropical latitudes the low-level air temperature actually increased by more than $10^{\circ} \mathrm{C}$ with respect to the "prefrontal" conditions, leading to the formation of a coastal low over central Chile at nearly the same time as the passage of the cold surge over central Argentina. Farther north along this coast, the conditions remain almost invariable.

To synthesize our analysis, Fig. 17 shows maps of the air temperature, winds, and vertical velocity at $850 \mathrm{hPa}$ at four instants during the simulation. Early in the simuIation (1200 UTC 14 April; see Fig. 17a) the cold front can be identified on both sides of the Andes at about $35^{\circ} \mathrm{S}$, with southerly cold advection behind it. Over the continent, strong ascent is found over the front while subsidence prevails farther south in connection with the postfrontal anticyclone; over the Pacific, there is only an interruption of the subsidence associated with the subtropical and the postfrontal anticyclones. A meridi- 


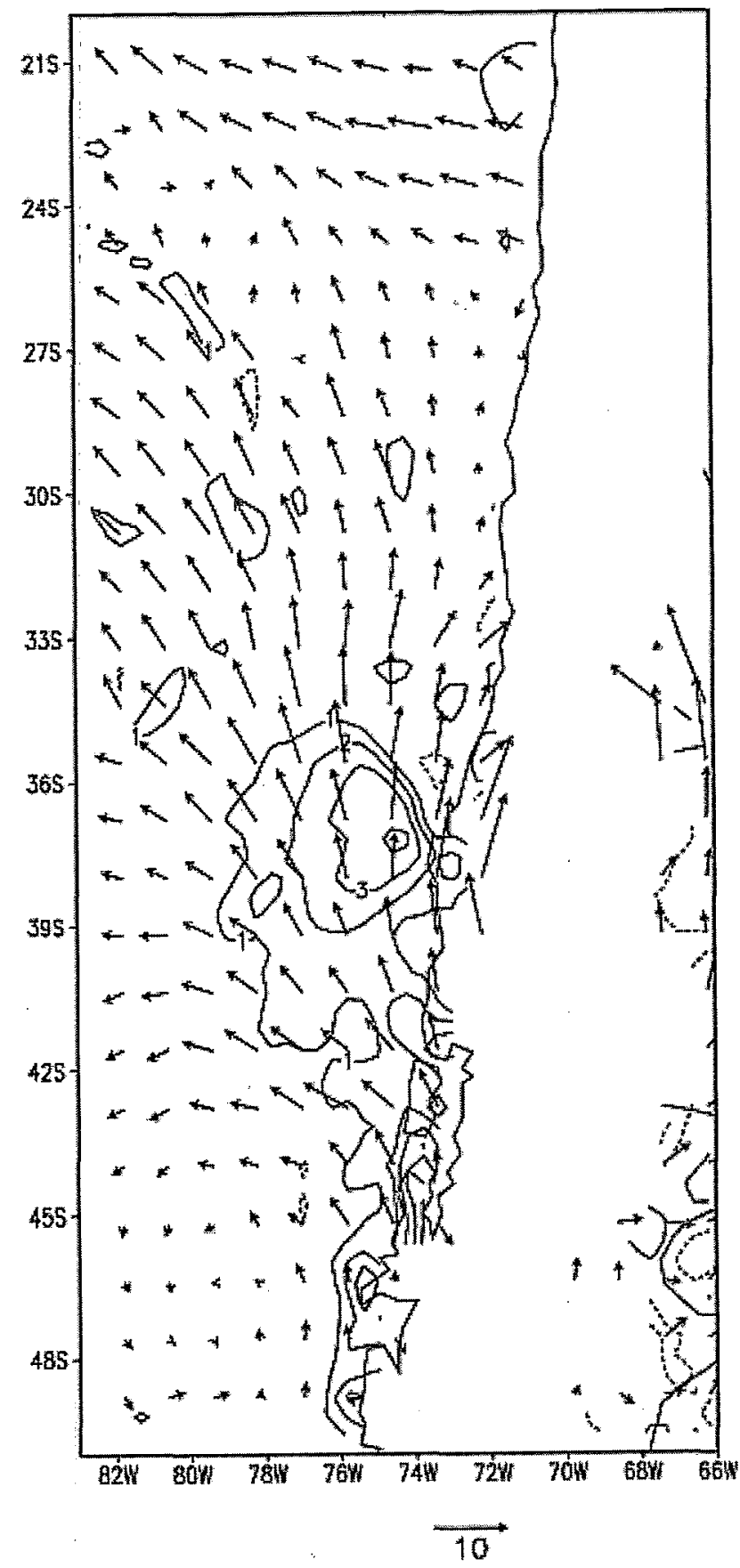

FIG. 15. Ageostrophic wind and horizontal divergence fields at $850 \mathrm{hPa}$ at $1800 \mathrm{UTC} 15 \mathrm{Apr} 1999$.

onal band of ascending motion is found to the south of $35^{\circ} \mathrm{S}$ as the westerly flow surpasses the Andes Cordillera. Twelve hours later (Fig. 17b) cold advection is present on both sides of the Andes, but a low-level wind develops a subtle easterly component at subtropical latitudes in response to the anticyclone farther south. The tall and steep mountains effectively block the flow, as corroborated by parcel trajectories (not shown), leading to a very small zonal wind component
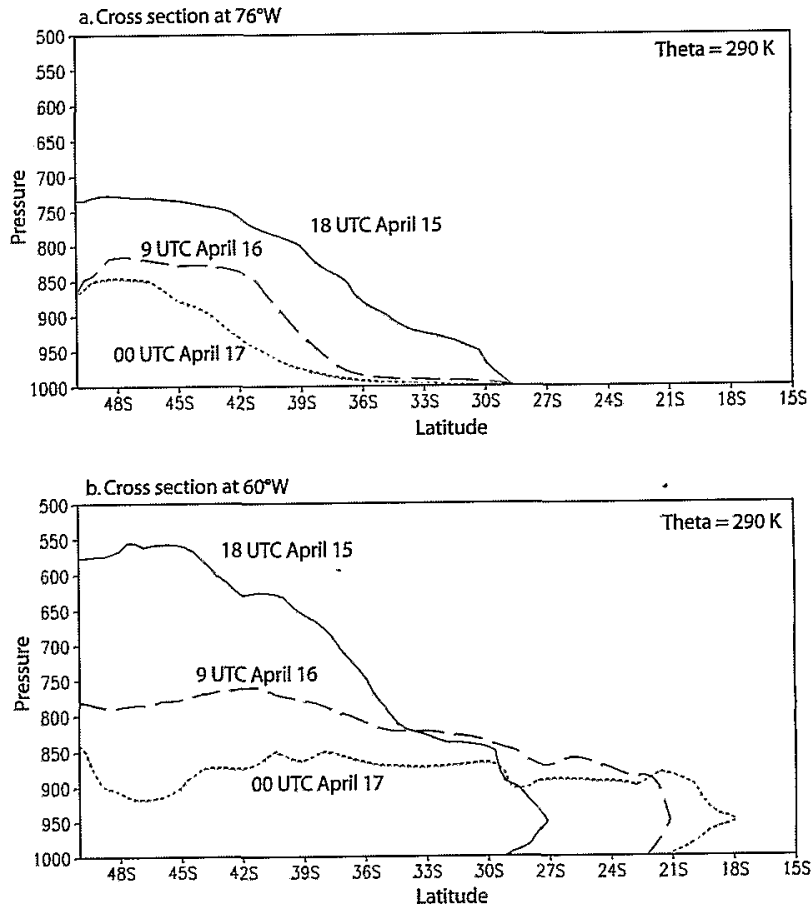

FIG. 16. Isochrones of $\theta=290 \mathrm{~K}$ on a pressure-latitude cross section at (top) $76^{\circ}$ and (bottom) $60^{\circ} \mathrm{W}$.

close to the slopes. Convergence (divergence) of the zonal flow to the east (west) of the subtropical Andes is largely compensated for by upward (downward) motion, and the associated cooling (warming) over this region.

At 1200 UTC 15 April (Fig. 17c), the easterly flow is very clear on both sides of the Andes. To the west of the mountains, the subsidence warming offsets the horizontal cold advection, limiting the advance of the cold front in this region. Moreover, horizontal cold advection has decreased since winds become almost parallel to the isotherms off the coast. In contrast, to the east of the Andes the vertical advection acts in concert with the horizontal advection. The blocking effect of the Andes also breaks down the geostrophic balance, accelerating the southerly winds over the continent and fostering the rapid advance of the cold front over the continent. By 1200 UTC 16 April (Fig. 17d), the cold air reached Bolivia and southwest Brazil, helped by horizontal and vertical advection. Later on, however, warming due to postfrontal subsidence, radiation, and moist processes lead the temperature tendency, beginning the frontolysis. To the west of the Andes the coastal area of warm air reaches its maximum extent $\left(25^{\circ}-36^{\circ} \mathrm{S}\right)$, followed by a progressive shrinking as subsidence begins to decrease, in connection with an incoming midlevel trough.

In summary, the differential evolution of the cold air 
a. 1200 UTC Apr 14

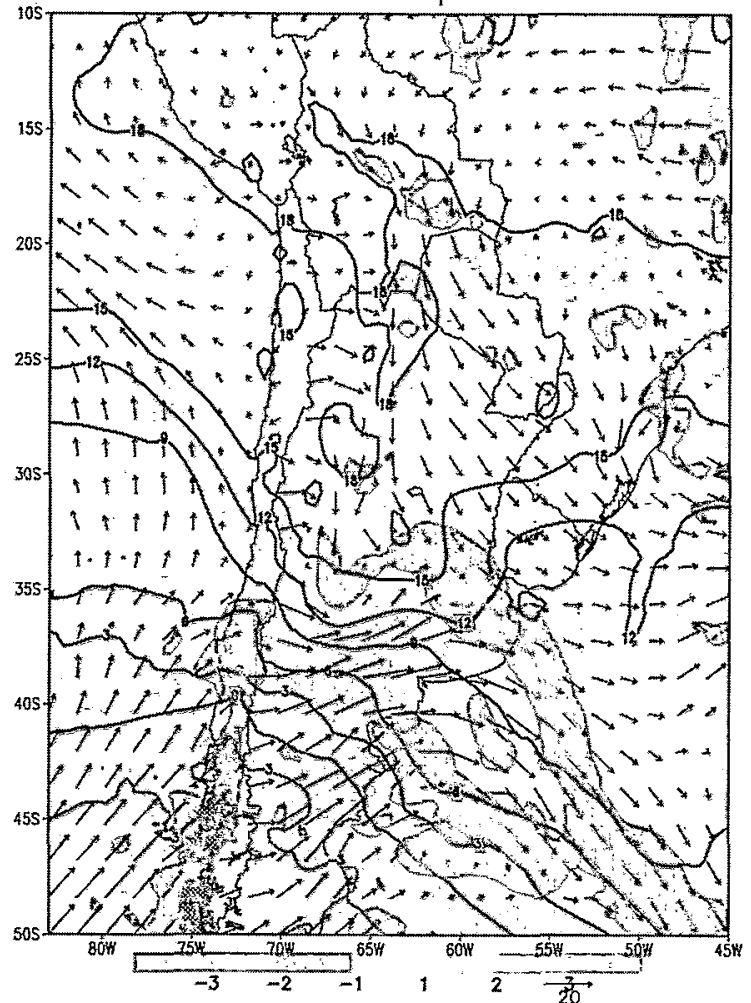

C. 1200 UTC Apr 15

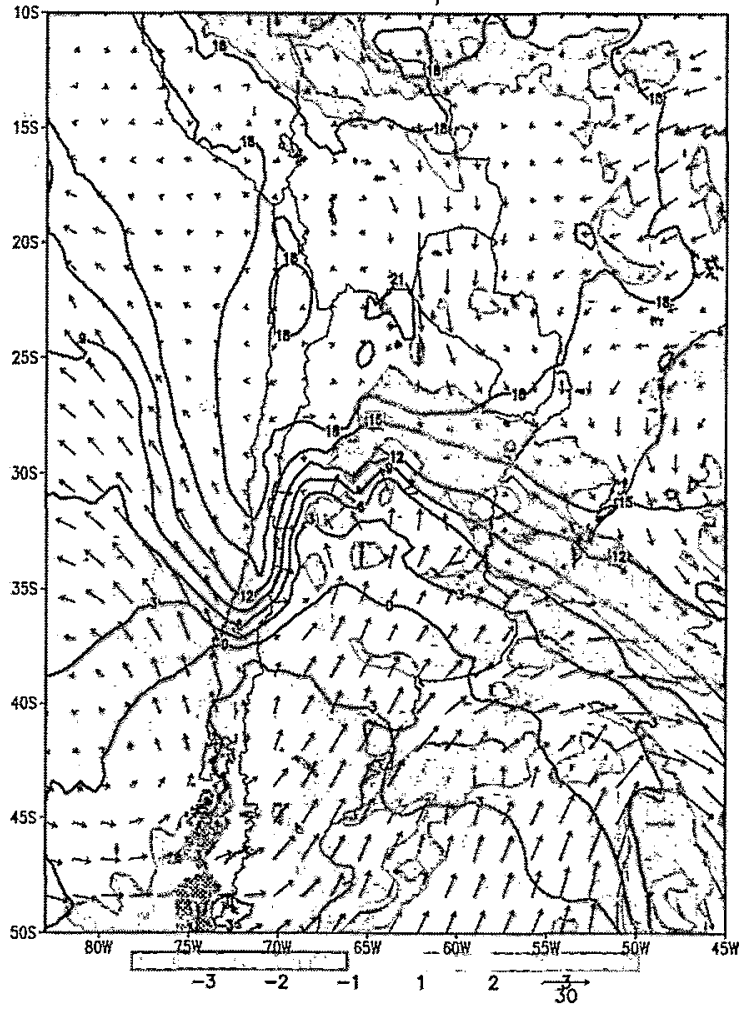

b. 0000 UTC Apr 15

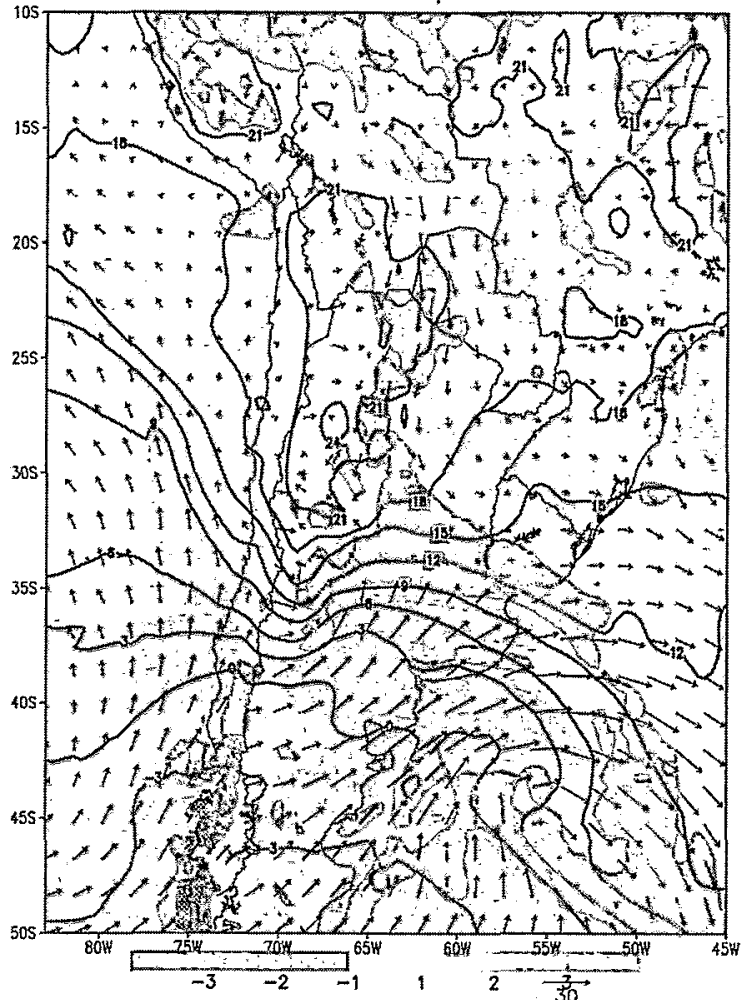

d.1200 UTC Apr 16

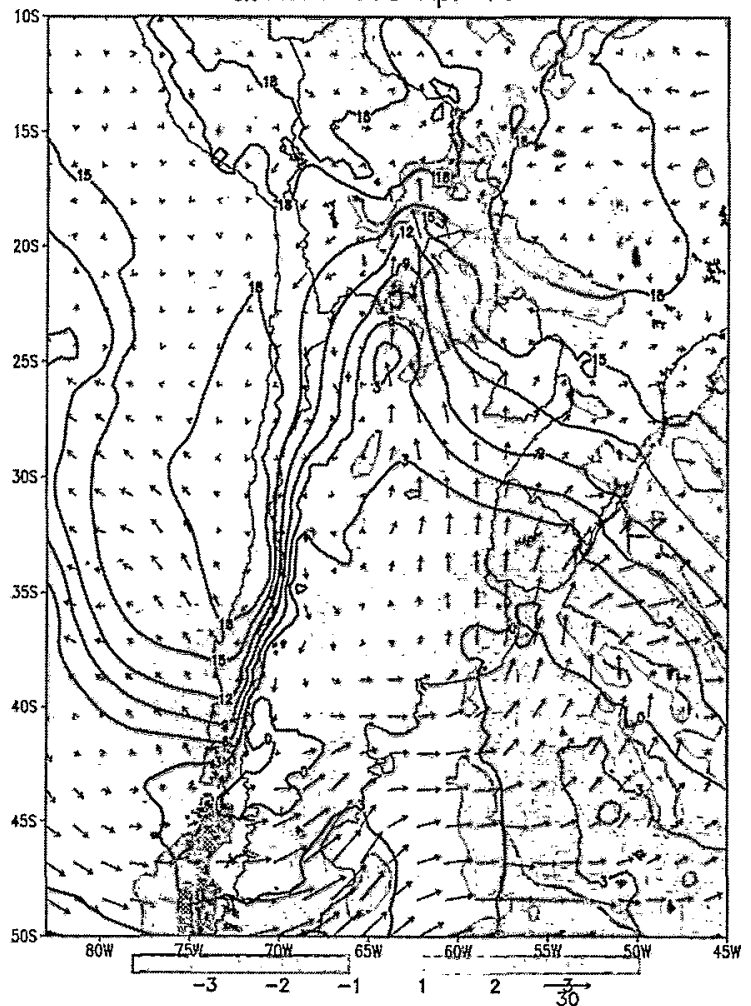

FIG. 17. Temperature contours (contoured every $3^{\circ} \mathrm{C}$ ), wind vectors $\left(\mathrm{m} \mathrm{s}^{-1}\right)$, and omega vertical velocity (shaded in hPa $\mathrm{s}^{-1}$ ) at the $850-\mathrm{hPa}$ level, at (top left) $1200 \mathrm{UTC} 14 \mathrm{Apr}$, (top right) $1000 \mathrm{UTC} 15 \mathrm{Apr}$, (bottom left) $1200 \mathrm{UTC} 15 \mathrm{Apr}$, and (bottom right) 1200 UTC 16 Apr 1999. 
dome on each side of the Andes is due to the blocking effect of the cordillera upon the low-level zonal flow. The decrease of the easterlies near the eastern foothills leads to an intensification of the ascending motion and vertical cooling, as well as to an acceleration of the southerly winds that advect cold air, contributing to the advance of the cold front. The increase of the easterlies off the coast is compensated for by subsidence to the west of the Andes, hindering the frontal advance in this region. The differential frontal evolutions over South America thus share some ingredients with similar conditions over North America and Australia, although in the case documented in this study (generally applicable to other cold surges/coastal lows), the Andes not only disrupt the horizontal flow (leading to significant ageostrophic circulation) but also induce strong vertical movements that play a key role on the thermal field.

Acknowledgments. This work was partially funded by the Ministry of Science and Technology of Brazil through Projects AC-61 and 490353/2004-5 of the PROSUL program. Constructive criticisms from the anonymous reviewers greatly contributed to improvements to this article.

\section{REFERENCES}

Betts, A. K., and M. J. Miller, 1986: A new convective adjustment scheme. Part II: Single column test using GATE wave, BOMEX, and arctic air-masses data sets. Quart. J. Roy. Meteor. Soc., 112, 1306-1335.

Black, T. L., 1994: The new NMC mesoscale Eta Model: Description and forecast examples. Wea. Forecasting, 9, 256-278.

Bluestein, H. B., 1993: Observations and Theory of Weather Systems. Vol. II, Synoptic-Dynamic Meteorology in Midlatitudes, Oxford University Press, $953 \mathrm{pp}$.

Chen, F., and Coauthors, 1996: Modeling of land surface evaporation by four schemes and comparison with FIFE observations. J. Geophys. Res., 101, 7251-7268.

Colle, B. A., and C. F. Mass, 1995: The structure and evolution of cold surges east of the Rocky Mountains. Mon. Wea. Rev., 123, 2577-2610.

Dallavalle, J. P., and L. F. Bosart, 1975: A synoptic investigation of anticyclogenesis accompanying North American polar air outbreaks. Mon. Wea. Rev., 103, 941-957.

Fels, S. B., and M. D. Schwarzkopf, 1975: The simplified exchange approximation: A new method for radiative transfer calculations. J. Atmos. Sci., 32, 1475-1488.

Fortune, M. A., and V.E. Kousky, 1983: Two severe freezes in Brazil: Precursors and synoptic evolution. Mon. Wea. Rev., 111, 181-196.

Gan, M. A., and V.B. Rao, 1994: The influence of the Andes Cordillera on transient disturbances. Mon. Wea. Rev., 122, 1141-1157.

Garreaud, R. D., 1999: Cold air incursions over subtropical and tropical South America. A numerical case study. Mon. Wea. Rev., 127, 2823-2853.

- 2000: Cold air incursions over subtropical South America:
Mean structure and dynamics. Mon. Wea. Rev., 128, 25442559.

and J. Rutllant, 2003: Coastal lows along the subtropical west coast of South America: Numerical simulation of a typical case. Mon. Wea. Rev., 131, 891-908.

, - - and H. Fuenzalida, 2002: Coastal lows along the subtropical west coast of South America: Mean structure and evolution. Mon. Wea. Rev., 130, 75-88.

Gill, A.E., 1982: Atmosphere-Ocean Dynamics. International Geophysics Series, Vol. 30, Academic Press, 662 pp.

Hamilton, G. M., and R. J. Tarifa, 1978: Synoptic aspects of a polar outbreak leading to frost in tropical Brazil, July 1972. Mon. Wea. Rev., 106, 1545-1556.

Janjić, Z. I., 1979: Forward-backward scheme modified to prevent two-grid-interval noise and its application in sigma coordinate models. Contrib. Atmos. Phys., 52, 69-84.

_, 1994: The step-mountain eta coordinate model: Further developments of the convection viscous sublayer and turbulence closure schemes. Mon. Wea. Rev., 122, 927-945.

Konrad, Ch. E., and S. J. Colucci, 1989: An examination of extreme cold air outbreaks over eastern North America. Mon. Wea. Rev., 117, 2687-2700.

Lacis, A. A., and J. E. Hansen, 1974: A parameterization of the absorption of solar radiation in the earth's atmosphere. $J$. Atmos. Sci., 31, 118-133.

Marengo, J., A. Cornejo, P. Satyamurty, C. Nobre, and W. Sea, 1997: Cold surges in tropical and extratropical South America: The strong event in June 1994. Mon. Wea. Rev., 125, 2759-2786.

Mass, C.F., and M.D. Albright, 1987: Coastal southerlies and alongshore surges of the west coast of North America: Evidences of mesoscale topographically trapped response to synoptic forcing. Mon. Wea. Rev., 115, 1707-1738.

McInnes, K. L., and J. L. McBride, 1993: Australian southerly busters. Part I: Analysis of a numerically simulated case study. Mon. Wea. Rev, 121, 1904-1920.

Mesinger, F, 1984: A blocking technique for representation of mountains in atmospheric models. Riv. Meteor. Aeronaut., 44, 195-202.

— and T. L. Black, 1992: On the impact on forecast accuracy of the step-mountain (eta) vs. sigma coordinate. Meteor. Atmos. Phys., 50, 47-60.

Muñoz, R., and R. Garreaud, 2005: Dynamics of the low-level jet off the subtropical west coast of South America. Mon. Wea. Rev., 133, 3661-3677.

Norte, F. A., 1988: Características del viento Zonda en la Región de Cuyo (Characteristics of the zonda wind in the Cuyo region). Ph.D. thesis, Ciudad University, Buenos Aires, Argentina, $224 \mathrm{pp}$.

Nuss, W., and Coauthors, 2000: Coastally trapped wind reversals: Progress toward understanding. Bull. Amer. Meteor. Soc., 81, 719-743.

Ogaz, P., and H. Fuenzalida, 1981: Acerca de un paso frontal y sus manifestaciones en el litoral árido del norte de Chile. Tralka, 2, 19-38.

Reason, C., and R. M. Jury, 1990: On the generation and propagation of the southern Africa coastal lows. Quart. J. Roy. Meteor. Soc., 116, 1133-1151.

Rutllant, J., and R. Garreaud, 2004: Episodes of strong flow down the western slope of the subtropical Andes. Mon. Wea. Rev., 132, 611-622.

Satyamurty, P., R. Pinheiro Dos Santos, and M. A. Maringolo 
Lemes, 1980: On the stationary trough generated by the Andes. Mon. Wea. Rev., 108, 510-520.

Schultz, D. M., W. E. Bracken, L. F. Bosart, G. J. Hakim, M. A. Bedrick, M.J. Dickinson, and K. R. Tyle, 1997: The 1993 Superstorm cold surge: Frontal structure, gap flow, and tropical impact. Mon. Wea. Rev., 125, 5-39.

Seluchi, M. E., and J. A. Marengo, 2000: Tropical-midlatitude exchange of air masses during summer and winter in South America: Climatic aspects and examples of intense events. Int. J. Climatol., 20, 1167-1.190.

, and S. C. Chou, 2001: Evaluation of two Eta Model versions for weather forecast over South America. Geofis. Int., 40, 219-237.

-, V. Y. Serafini, and H. Le Treut, 1998: The impact of the
Andes on transient atmospheric systems: A comparison between observations and GCM results. Mon. Wea. Rev., 126, 895-912.

- F. A. Norte, P. Satyamurty, and S. C. Chou, 2003a: Analysis of three situations of the foehn effect over the Andes (zonda wind) using the Eta-CPTEC regional model. Wea. Forecasting, 18, 481-501.

—, A. C. Saulo, M. Nicolini, and P. Satyamurty, 2003b: The northwestern Argentinean low: A study of two typical events. Mon. Wea. Rev., 131, 2361-2378.

Vera, C. S., and P. Vigliarolo, 2000: A diagnostic study of cold-air outbreaks over South America. Mon. Wea. Rev., 128, 3-24.

Zhao, Q., and F. H. Carr, 1997: A prognostic cloud scheme for operational NWP models. Mon. Wea. Rev., 125, 1931-1953. 


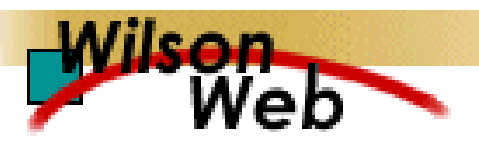

\section{COPYRIGHT INFORMATION}

TITLE: Influence of the Subtropical Andes on Baroclinic

Disturbances: A Cold Front Case Study

SOURCE: Mon Weather Rev 134 no11 N 2006

WN: 0630501615019

The magazine publisher is the copyright holder of this article and it is reproduced with permission. Further reproduction of this article in violation of the copyright is prohibited. To contact the publisher: http://www.ametsoc.org/AMS/

Copyright 1982-2006 The H.W. Wilson Company. All rights reserved. 